IZA DP No. 9836

Education as a Tool for the Economic Integration of Migrants

Maria De Paola

Giorgio Brunello

March 2016 


\title{
Education as a Tool for the Economic Integration of Migrants
}

\author{
Maria De Paola \\ University of Calabria \\ and IZA \\ Giorgio Brunello \\ University of Padova, \\ EENEE and IZA
}

Discussion Paper No. 9836

March 2016

IZA

P.O. Box 7240

53072 Bonn

Germany

Phone: +49-228-3894-0

Fax: +49-228-3894-180

E-mail: iza@iza.org

\begin{abstract}
Any opinions expressed here are those of the author(s) and not those of IZA. Research published in this series may include views on policy, but the institute itself takes no institutional policy positions. The IZA research network is committed to the IZA Guiding Principles of Research Integrity.

The Institute for the Study of Labor (IZA) in Bonn is a local and virtual international research center and a place of communication between science, politics and business. IZA is an independent nonprofit organization supported by Deutsche Post Foundation. The center is associated with the University of Bonn and offers a stimulating research environment through its international network, workshops and conferences, data service, project support, research visits and doctoral program. IZA engages in (i) original and internationally competitive research in all fields of labor economics, (ii) development of policy concepts, and (iii) dissemination of research results and concepts to the interested public.
\end{abstract}

IZA Discussion Papers often represent preliminary work and are circulated to encourage discussion. Citation of such a paper should account for its provisional character. A revised version may be available directly from the author. 


\section{ABSTRACT}

\section{Education as a Tool for the Economic Integration of Migrants ${ }^{*}$}

We examine the role of education in fostering the economic integration of immigrants. Although immigrants in Europe are - on average - slightly less educated than native individuals, there is a large heterogeneity across countries. We discuss evidence on student performance in international tests showing that children with an immigrant background display worse results than natives. While in some countries, such as Denmark and France, this gap is almost entirely explained by differences in socio-economic background, in others (Finland, Austria, Belgium and Portugal) the factors driving the gap are more complex and have roots also outside socio-economic conditions. We investigate how educational policies in the host count can affect the educational outcomes of immigrants. We focus our attention on pre-school attendance, school tracking, the combination of students and teacher characteristics, and class composition.

JEL Classification: $\quad$ I20, I21, I28, J24. J61

Keywords: education, immigration, European migration policies, school tracking, class composition

Corresponding author:

Maria De Paola

Dipartimento di Economica, Statistica e Finanza

Università della Calabria

87036, Arcavacata di Rende

Italy

E-mail:m.depaola@unical.it

\footnotetext{
* This paper is an adapted version of an analytical report prepared by the European Expert Network on Economics of Education (EENEE) for the European Commission. We are grateful to Kristina Cunningham, Ruth Schuler, Martina Viarengo and an anonymous referee for comments on an earlier draft. The opinions expressed in this paper are those of the authors alone and do not necessarily represent the point of view of the European Commission. The usual disclaimer applies.
} 


\section{Introduction}

International migration has accelerated during the last decades. According to the United Nations (2013), between 1990 and 2013 the number of international migrants worldwide rose by over 77 million (50 per cent) and much of this growth occurred between 2000 and 2010. However, migration has not increased everywhere: while net immigration to Northern America declined from 1.4 million annually in 1990-2000 to 1.3 million per year in 2000-2010, it almost doubled in Europe over the same period, from one million to 1.9 million per year.

Migratory flows have become more complex, with an increasing diversity of immigrants, and the division between immigration and emigration countries has become less clear-cut (Czaika and de Haas, 2014). Large scale immigration is a recent phenomenon for Europe, as the share of foreign born population was very small before 1960 in almost all European countries. Countries such as Italy and Spain, which have historically been characterized by important emigration, are now experiencing significant immigration.

Nowadays, Europe is also facing a growing refugees crisis: a large number of persons have recently reached the continent in search of safety, and more than 700,000 have claimed asylum in 2015 (Eurostat). While the conflict in Syria is one of the main drivers of the current crisis - the United Nations estimates that half a million Syrian refugees have sought asylum in Europe between April 2011 and September 2015 - ongoing violence in Afghanistan and in Eritrea and poverty in Kosovo are also pushing people to leave their countries. The economic and social consequences of these large inflows of refugees are debated by both academics and politicians. According to the United Nations' definition, refugees are persons who, because of the well-founded fear of being persecuted for reasons of race, religion, nationality, membership of a particular social group or political opinion, are outside the country of their nationality and are unable to return. This group raises specific issues that are different from those posed by immigrants.

In this report, we focus on immigrants and examine the role played by education in enhancing their economic integration. We describe the educational composition of immigrants in Europe and examine the factors explaining why their educational outcomes differ with respect to non-immigrants. After investigating how the organization of school systems affects the education of immigrant children, we turn to the key question as to whether the share of immigrants in schools affects the school performance of non-immigrants. Finally, we discuss whether the education of the population can help in mitigating anti-immigration sentiments, thereby favouring the integration process of immigrants. In our review of the existing research, we are particularly interested in studies that can identify causal 
effects, as it is the presence of these effects that can motivate policy intervention. While our focus is mainly on Europe, we shall also consider important evidence from the US.

Human capital is a key factor in the integration process, because of its strong impact both on the probability of employment and on wages, which are key to socio-economic integration. Empirical evidence shows that - on average - immigrants in Europe are less educated than non-immigrants. However, there is large heterogeneity across countries. A first group, including the UK and Ireland is characterised by a high-skilled foreign-born population, while a second group (France, Germany, and the Netherlands) has mainly a low-skilled foreign-born population. In the middle there are countries where foreign and native populations show rather comparable educational levels (Spain and Italy) (Dustmann et al., 2012).

Generally, second generation migrants have higher education than their first-generation counterparts and in some cases even outperform native populations. ${ }^{1}$ In several countries, however, education gaps between second generation immigrants and native individuals persist. For instance, it has been shown that in most countries second generation immigrants on average have lower reading and math test scores than the children of native parents.

Whereas in some countries the causes of these test score gaps can be imputed to differences in socio-economic background and to deficiencies in host country language proficiency, in other countries the sources of these gaps are not easy to identify. Family background accounts for the entire achievement disadvantage in Denmark and France and for the bulk of it in Central European countries, but in Finland, Austria and Belgium large differences remain between immigrants' children and children of native parents even after controlling for family characteristics (Dustmann et al. 2012). These differences point to the fact that the policies required to foster the integration of immigrants may have to vary across countries. Similar considerations could be made when we look at the results of the literature that examine the importance of language skills both for educational attainment and for labour market outcomes. Since European countries show marked differences in the percentage of children of immigrants who speak the language of the host country, they might face different challenges.

While the educational investment of first generation immigrants was almost entirely completed in the country of origin, the immigrants who have arrived as children and second generation immigrants typically undertake their investments in human capital in the host country. Because of this, European educational institutions have an important role to play in bridging the gap in educational attainment between native and immigrant populations. Recent economic literature has pointed out the importance

\footnotetext{
${ }^{1}$ We define as first generation immigrants the foreign-born individuals who migrate permanently, or at least for an extended period, from one country to another, and as second generation immigrants the individuals born in the host country as offspring of at least one immigrant parent.
} 
of institutional features such as preschool and school entry age, teacher-pupils ratios, class composition and school tracking.

This literature suggests that immigrant integration can be enhanced by using free pre-school programs and by recruiting teachers with an immigrant background, who can help immigrant children by establishing positive role models. Since teachers have been shown to often assess ethnic minority students in ways that deviate from what would be expected from national standardized tests, training programs aimed at changing stereotyped teachers' attitudes toward immigrants might also be useful. Although the early tracking systems differentiating between vocational and academic education that characterise some European countries are often viewed as a barrier for children with an immigrant background, because selection into tracks takes place before they have acquired good language skills, the evidence on the effects produced by these systems on immigrants remains scant and mixed. Evidence from studies that address the fact that both immigrant and native students self - select into different school curricula and tracks suggests that while in general delaying tracking does not help reducing the "immigrant-native" attainment gap, such policies may be useful for children with a disadvantaged socio-economic background.

Another factor that might affect the school performance of both children with immigration background and native children is the share of non-native peers in the class or school. ${ }^{2}$ How native and immigrant students are arranged across classes changes educational outcomes both because children with an immigrant background might require special attention by teachers and because of peer effects. On the one hand, totally segregated systems might allow organizing teaching activity in a way that responds better to student needs. On the other hand, they might hamper social interaction between immigrant and native children, with negative consequences for integration. The empirical evidence to date, both from the US and Europe, indicates that having a high share of immigrants in the class has detrimental effects on children with an immigrant background.

What about native children? Even if parents of native children and politicians might fear that having too many immigrant students in the class or school might negatively affect the school performance of the children of native parents, the results from academic research are mixed. While some studies report sizeable negative effects, other studies find small or zero effects. These ambiguous results could partly be due to the fact that the identification of peer effects is fraught with difficulties. Immigrant and native children are not randomly assigned to schools but self-select on the basis of their predetermined observable and unobservable characteristics. Moreover, class composition is typically decided by the

\footnotetext{
${ }^{2}$ We are aware that, in a mobile society, the dichotomy immigrants/natives may be somewhat simplistic. In this report, we intend this distinction not as a dichotomy but as a convenient classification, that closely follows the one used in the economic literature.
} 
school administration. These selection mechanisms raise a number of empirical issues that have not been entirely solved by the existing research.

The economic integration of immigrants also depends on attitudes shown by the native population. Empirical evidence shows that better educated individuals are more open, have a stronger preference for cultural diversity and a favourable attitude toward immigrants. However, the positive correlation between education and immigration attitudes, found by most of the empirical research in the area, cannot be interpreted as causal, because of the presence of many individual unobserved characteristics that might affect both investments in education and immigration attitudes. Only few studies have investigated this issue by using robust estimation strategies. Their findings also suggest that a more educated native population is more likely to facilitate the inclusion of immigrants.

\section{Human capital investments and immigrants' integration}

Because of its effects on employment and wages, human capital is a key factor for the economic success of immigrants in the host country. For most first generation immigrants, the process of human capital accumulation starts with the education and skills acquired in the home country prior to immigration, and in some cases it continues in the host country with additional investments in education, training and learning by doing. While distinguishing between these two components of human capital is often not possible because of lack of suitable data, the first component, captured mainly by the level of schooling completed in the home country, is for many adult immigrants the most relevant one as they typically do not undertake additional investments in education in the host country.

Since education is strictly related to earnings and differences in education attainment tend to persist over subsequent immigration generations, ${ }^{3}$ the composition of immigrants by education is important in order to understand their economic impact on the host country, for instance in terms of tax payments and GDP. A first attempt to look at this composition is Docquier and Marfouk (2004, 2006), who use data from a large number of OECD countries to provide a detailed overview of worldwide international mobility by educational attainment, focusing on the so-called brain-drain phenomenon. Dustmann and Glitz (2011) undertake a similar exercise and look at the average educational attainment of the foreign-born population in the ten most important immigrant receiving countries in the OECD around the year 2000. Considering the educational attainment of immigrants in relation to that of natives, they divide OECD host countries into three groups: a first group characterised by a high-

\footnotetext{
${ }^{3}$ Dustmann et al. (2012) show that immigrant children's educational attainment is strongly correlated with the education of their parents. In the countries where immigrants are highly educated (Australia, UK and Canada), their children's educational attainments are similar to those of natives, or - in the case of Australia - even higher. On the other hand, in countries where immigrants have a lower level of education than natives, their children tend to achieve substantially lower levels of education than natives.
} 
skilled foreign-born population (Australia, Canada, and the UK), a second group characterized by a low-skilled foreign-born population (France, Germany, the Netherlands, Switzerland and the U.S.), and a third group where foreign and native populations show relatively comparable educational levels (Spain and Italy).

Dustmann and Frattini (2011) use three waves of the European Labour Force Survey (EULFS) ${ }^{4}$ (2007, 2008 and 2009) and focus on 15 Western European countries, 14 members of the European Union and Norway. They show that - on average - immigrants in these countries are slightly less educated than native individuals. There is, however, heterogeneity across countries. ${ }^{5}$ For instance, the percentage of immigrants with tertiary education is higher than that of natives in Ireland, Norway, Portugal, Sweden and UK, and lower in Belgium, Finland, Italy and Spain. ${ }^{6}$

A more detailed picture is provided by Table 1 (drawn from Sweetman and van Ours, 2014, and mainly based on OECD data), ${ }^{7}$ showing for each country the percentages of natives, first generation and second generation immigrants with lower-secondary education (below ISCED level 3) and the percentages of natives, first and second generation immigrants with tertiary education (ISCED levels 5 and above).

The educational levels of first and second generation immigrants are strictly correlated. The evidence surveyed by Dustmann and Glitz (2011) suggests that intergenerational mobility is lower for immigrants than for natives and that education is the main driver of the strong intergenerational linkages between immigrant fathers and their children. These patterns vary across countries: relatively high intergenerational mobility in Scandinavian countries, modest in Canada and Germany and relatively low in the U.S. Existing studies also suggests that an important role in the intergenerational mobility of immigrants is played by the average quality of the ethnic environment in which children are raised, the so-called "ethnic capital". This capital has a significant effect on the educational attainment of second generation children, similar in size to that produced by parental education (Borjas, 1992; Borjas, 1995; Aydemir et al. 2009).

\footnotetext{
${ }^{4}$ The EULFS is large quarterly household sample survey of individuals aged at least 15, that harmonizes data collected in the 27 Member States of the European Union and 2 countries of the European Free Trade Association (EFTA).

${ }^{5}$ Dustmann and Frattini (2011) also show that there is heterogeneity in the educational attainment of different immigrant groups within the same destination country. They investigate differences in educational attainments across countries of origin (pooling all European countries of destination) and find that North American and Oceanian immigrants are substantially better educated than natives, while non-EU European and North African immigrants have lower levels of education than natives.

6 A similar picture emerges also when considering data from the International Migration Outlook 2014 providing information on a large number of countries.

7 In the table we use a dash to indicate that data are missing, due to different definitions across countries.
} 
Table 1: Educational attainment by generation and immigrant status. Selected countries.

\begin{tabular}{|c|c|c|c|c|c|c|c|c|}
\hline & \multicolumn{4}{|c|}{$\begin{array}{l}\text { Percentage with low education } \\
\text { (Below ISCED 3) }\end{array}$} & \multicolumn{4}{|c|}{$\begin{array}{l}\text { Percentage with high education } \\
\text { (ISCED } 5 \text { and above) }\end{array}$} \\
\hline & \multirow[t]{2}{*}{ Natives } & \multirow{2}{*}{$\begin{array}{l}\text { First } \\
\text { Gen. }\end{array}$} & \multicolumn{2}{|c|}{ Second Generation } & \multirow[t]{2}{*}{ Natives } & \multirow{2}{*}{$\begin{array}{l}\text { First } \\
\text { Gen. }\end{array}$} & \multicolumn{2}{|c|}{ Second Generation } \\
\hline & & & $\begin{array}{l}\text { one } \\
\text { immigrant } \\
\text { parent }\end{array}$ & $\begin{array}{l}\text { both } \\
\text { parents } \\
\text { immigrant }\end{array}$ & & & $\begin{array}{l}\text { one } \\
\text { immigrant } \\
\text { parent }\end{array}$ & $\begin{array}{l}\text { both } \\
\text { parents } \\
\text { immigrant }\end{array}$ \\
\hline Austria & 12 & 27 & 13 & 24 & 19 & 19 & 24 & - \\
\hline Belgium & 23 & 36 & 32 & 33 & 36 & 32 & 30 & 20 \\
\hline Canada & 24 & 23 & 19 & 14 & 37 & 45 & 44 & 50 \\
\hline Cyprus & 20 & 23 & - & - & 39 & 37 & 46 & - \\
\hline Czech Republic & 7 & 18 & 9 & 29 & 16 & 21 & 13 & - \\
\hline Denmark & 21 & 29 & - & - & 36 & 34 & - & - \\
\hline Estonia & 11 & - & 12 & 8 & 27 & 21 & 28 & 14 \\
\hline France & 23 & 43 & 24 & 26 & 31 & 26 & 35 & 29 \\
\hline Germany & 8 & 34 & - & 19 & 27 & 21 & 28 & 14 \\
\hline Greece & 32 & 47 & - & 40 & 26 & 15 & 30 & - \\
\hline Hungary & 18 & 14 & - & - & 20 & 31 & 26 & - \\
\hline Ireland & 28 & 16 & 19 & - & 34 & 47 & 47 & 53 \\
\hline Italy & 42 & 44 & 27 & - & 16 & 12 & 25 & - \\
\hline Lithuania & 7 & - & - & - & 32 & - & - & - \\
\hline Luxembourg & 28 & 31 & 27 & 23 & 26 & 37 & 17 & 17 \\
\hline Netherlands & 22 & 39 & 24 & 29 & 35 & 27 & 35 & 29 \\
\hline New Zealand & 20 & - & 22 & 17 & 29 & - & 29 & 34 \\
\hline Poland & 10 & - & 11 & - & 22 & 51 & 18 & 16 \\
\hline Portugal & 70 & 50 & 53 & 59 & 15 & 22 & 28 & - \\
\hline Slovak Republic & 8 & - & - & - & 15 & 26 & 18 & - \\
\hline Slovenia & 14 & 34 & - & - & 25 & - & 27 & - \\
\hline Spain & 43 & 40 & 33 & 55 & 35 & 24 & 40 & 21 \\
\hline Sweden & 13 & 29 & 14 & 15 & 34 & 35 & 32 & 28 \\
\hline Switzerland & 5 & 27 & 6 & 7 & 36 & 35 & 39 & 31 \\
\hline United Kingdom & 25 & 20 & 20 & 22 & 33 & 34 & 43 & 45 \\
\hline United States & 10 & 31 & 5 & 11 & 40 & 34 & 45 & 45 \\
\hline
\end{tabular}

Source: Sweetman and van Ours 2014, page. 44. Datasets: Eurostat (2011), American CPS (1998-2004), Canadian census data (2006); Australian Bureau of Statistics (2009).

The heterogeneity characterizing European countries can be explained by a number of factors. Apart from historical reasons, a crucial role is played by immigration policies: whether a country applies immigrant selection policies (aimed at attracting high skilled immigrants) or policies emphasizing "guest worker" recruitment, family reunification or refugee movements, shapes the average educational level of first generation immigrants and also affects, via intergenerational transmission, the educational attainment of following generations. The features of the labour market in each country might also be relevant, since immigrants with a high level of education are likely to prefer destination countries paying 
a high skill premium. Institutional features matter too. Some of these features, such as the openness of the educational system, even if more directly linked to the educational attainment of second generation immigrants, might also influence the average educational level of first generation immigrants who may choose the destination country by taking into account the expected utility for their offspring. If individuals who have acquired a high level of education at home assign a high value to their children' educational opportunities, they might decide to migrate to countries offering such opportunities.

An additional factor that has to be considered is return migration, the so-called "brain circulation". As discussed by Dustman and Glitz (2011), a large fraction of immigrants will at some point return to their home country. If immigrants plan to return home (or to move to a different country), their investments in human capital will be affected not only by the expected returns to these skills in the host country, but also by the returns in the home country - or in the new destination country. Therefore, an increase in the expected period of stay in the host country is likely to increase both immigrants' human capital investment in host country specific skills and parental investment in children's education. Dustmann (2008) illustrates this point by using German panel data and by including in his regressions information on parental return intentions. He shows that parental investment in children's education increases when the parent is more likely to be a permanent immigrant in the host country.

While the educational investments of first generation adult immigrants were typically almost entirely completed in their home country, young first generation immigrants and second generation immigrants undertake their investments in human capital in the host country. Since these investments are relevant for economic integration, it is important to understand whether and how they differ from those undertaken by native individuals. Are there large differences in this education gap across European countries? How do children with an immigrant background perform in the school systems of their host counties?

When comparing the educational attainment of immigrant and native children, the literature finds that relevant gaps penalising immigrants are observed at very early ages, implying that children with an immigrant background and children of native parents start school from different levels of school readiness - in terms of both cognitive and non-cognitive skills (Rouse et al. 2005, Lahaie, 2008). For instance, Biedinger et al., 2008, use data from the school entrance examination for the City of Osnabrück in Germany for the years 2000-2005 to show that children with an immigrant background have lower school readiness scores ${ }^{8}$ than children of native parents even after controlling for family background variables and pre-school experience. These gaps are likely to have permanent consequences and to affect subsequent educational attainment. In fact, as shown by Heckman (2000), early childhood development is crucial and directly influences economic, health and social outcomes for individuals and society.

\footnotetext{
${ }^{8}$ These scores are based on school entrance examination data.
} 
Attainment is usually measured as completed years of schooling. In general, children with an immigrant background display better outcomes compared to their first-generation counterparts and in some cases they also outperform children of native parents.' As shown by Table 1, there is remarkable heterogeneity across countries. In addition, as shown for instance by Dustman et al. (2012), there is a strong and statistically significant positive correlation between the education of parents and children across countries.

Educational attainment by second generation immigrants only captures the quantity of education, thereby ignoring both differences in school quality and other learning opportunities that occur in the household or in the labour market. A more encompassing measure of human capital is individual achievement as measured by standardised test scores (see Hanushek and Woessmann, 2012). The literature investigating the gap in test scores between immigrants and non-immigrants uses data from international achievement tests - such as PISA (Programme for International Student Assessment), PIRLS (Progress in International Reading Literacy Study), and TIMSS (Trends in International Mathematics and Science Study), that provide internationally comparable measures of proficiency in skills.

Many of the existing studies focus on specific countries. For instance, Algan et al. (2010) provide evidence for France, Germany and the UK; Murat (2011) for Italy and France; Gang and Zimmermann (2000) and Riphahn (2003) focus on Germany; Van Ours and Veenman, (2003) consider the Netherlands; Chiswick and Deb-Burman's (2004) look at the US and Dustmann and Theodoropoulos (2010) at the UK. A common trait of these studies is that they show that native students display a better performance in terms of test scores than both first and second generation immigrants.

Multi-country studies include Schnepf $(2007)^{10}$ and Dustmann et al. (2012). The latter study, using PISA data, confirms that second generation immigrants have lower reading and math test scores than the children of native parents in most countries, with the exception of Australia, Canada and Greece. The estimated achievement gap in reading for Central and Northern European countries ranges from 22 points for France to 80 points for Austria ${ }^{11}$. On the other hand, no significant differences are detected for the Anglo-Saxon European countries and Southern European countries. ${ }^{12}$

In an effort to understand the sources of variation in the educational achievement gap of immigrant children relative to children of native parents, Dustmann et al. (2012) control in their estimates for

\footnotetext{
${ }^{9}$ The "relative" advantage of second-generation immigrants compared to the first generation is related to the fact that they do not have to adapt to a new context and acquire a new language.

${ }^{10}$ Schnepf (2007) analyses - in a cross-country comparative perspective - standardized performance tests of children with an immigrant background, using PISA 2003, TIMSS 1995 and 1999, and PIRLS 2001 data. In her analysis, she considers Australia, Canada, France, Germany, the Netherlands, New Zealand, Sweden, Switzerland, the UK and the US.

${ }^{11}$ The average reading score for native pupils is about 515 in these countries.

${ }^{12}$ In Australia and Canada, children with an immigrant background perform better in reading tests than children of nativeborn parents.
} 
parental education and occupation and show that socioeconomic deprivation accounts for a substantial part of immigrant-native gaps in some countries, but not in others. While the gap vanishes (or becomes statistically not significant) in Denmark and France and it is markedly reduced in Central European countries, in other countries such as Finland, Austria, Belgium and Portugal large differences between immigrant and native children remain even after controlling for family background. Dustmann and coauthors show that differences in school characteristics, such as educational resources, class size and the proportion of teachers with a college degree have limited effects on the observed gap, contrary to what happens for measures of peer quality. ${ }^{13}$ As discussed more in detail in a later section, another important factor to consider is language skills.

Table 2 summarizes the evidence produced by Dustmann et al. (2012). The fact that parental background matters for the school results of second generation immigrants suggests that in some countries early policy interventions targeted at this group could significantly improve these results. However, these policies are unlikely to work in some other countries, where immigrant-native gaps remain even after controlling for a wide range of variables, including parental background and school characteristics, either because immigrants face specific costs in addition to those deriving from poor economic background and language deficiencies, or because children with an immigrant background may face disincentives to provide effort at school due to the fear of rejection by their communities (see for instance, Austen-Smith and Fryer, 2005).

It is important to stress that these results should be interpreted with care. They are not causal effects, because measures of school quality and the performance of immigrants can be driven by other (unmeasured) factors, or because performance itself may trigger government measures to improve schooling, that affect school characteristics.

Crul et al. (2012) show that immigrants' educational disadvantage varies across countries even when considering the same ethnicity group. Using their own collected data, they find that Turkish second generation immigrants in France and Sweden have the most favourable educational results, with low percentages of early school leavers and a considerable group of highly educated young people. Instead, in Germany, Belgium and Austria, second generation Turks show much less promising educational results, with a high percentage of early school leavers and a small share of individuals enrolled in tertiary education. Broad differences between students of similar socio - economic status and common

\footnotetext{
${ }^{13}$ Another well documented fact is the variation in test scores across children with different ethnic backgrounds, even after controlling for parental socio-economic status (Levels, Dronkers, and Kraaykamp, 2008; Levels and Dronkers, 2008). As shown for instance by Giannelli and Rapallini (2015), students whose parents come from countries that are highly reputed for their maths do perform better in PISA maths test scores. Crul et al. (2012) show that migrant educational disadvantage varies across countries even when considering the same ethnicity group.
} 
ethnicity emerge also from PISA (2012) test scores, suggesting that educational policies in the host country are relevant for students' performance. ${ }^{14}$

Table 2. Explained and Unexplained achievement Gaps (on the bases of Dustmann et al., 2012, estimation results)

\begin{tabular}{|c|c|c|}
\hline Country & Reading Gap & Math Gap \\
\hline & Fully explained by: & Fully explained by: \\
\hline Australia & Family background, school characteristics & $\begin{array}{l}\text { Family background, school characteristics, peer } \\
\text { quality, \% immigrants at school; language }\end{array}$ \\
\hline Austria & Persisting gap & Persisting gap \\
\hline Belgium & Persisting gap & Persisting gap \\
\hline Canada & $\begin{array}{l}\text { Family background, school characteristics, peer } \\
\text { quality }\end{array}$ & No gap \\
\hline Denmark & Family background & $\begin{array}{l}\text { Family background, school characteristics, peer } \\
\text { quality, \% immigrants at school; } \\
\text { Language }\end{array}$ \\
\hline Finland & Persisting gap & Persisting gap \\
\hline France & Family background & Family background \\
\hline Germany & Persisting gap & Persisting gap \\
\hline Greece & No gap & No gap \\
\hline Italy & No significant gap & No significant gap \\
\hline Netherlands & $\begin{array}{l}\text { Family background, school characteristics, peer } \\
\text { quality, \% immigrants at school }\end{array}$ & Persisting gap \\
\hline Norway & $\begin{array}{l}\text { Family background, school characteristics, peer } \\
\text { quality, \% immigrants at school; language }\end{array}$ & $\begin{array}{l}\text { Family background, School characteristics, peer } \\
\text { quality, \% immigrants at school; language }\end{array}$ \\
\hline Portugal & Persisting gap & Persisting gap \\
\hline Spain & No significant gap & $\begin{array}{l}\text { Family background, school characteristics, peer } \\
\text { quality }\end{array}$ \\
\hline Sweden & $\begin{array}{l}\text { Family background, school characteristics, peer } \\
\text { quality, \% immigrants at school }\end{array}$ & Persisting gap \\
\hline Switzerland & Persisting gap & Persisting gap \\
\hline UK & No significant gap & No significant gap \\
\hline USA & No significant gap & $\begin{array}{l}\text { Family background, school characteristics, peer } \\
\text { quality, \% immigrants at school; } \\
\text { Language }\end{array}$ \\
\hline
\end{tabular}

Source: Based on Dustmann et al, (2012).

\section{Language skills, educational achievement and labour market outcomes}

Proficiency in the host country language plays a crucial role for immigrants' integration. In this section, we will examine the role that language skills have in explaining the educational attainment of second generation immigrants and consider how these skills affect immigrants' labour productivity in the host country.

Language skills are the sub-stratum for building competency in many other domains: when studying math or science, immigrant children with poor proficiency in the host-country language face extra

\footnotetext{
${ }^{14}$ For instance immigrant students from Russia who are living in Germany outperform those living in Greece, even after taking into account socio-economic conditions.
} 
difficulties. As already mentioned in the previous section, Dustmann et al. (2012) show that in many countries language and family background are the most relevant factors driving the immigrant-native educational gap. For students who do not speak the host-country language at home, the difference in math test scores relative to their native counterparts is large in some countries (close to 20 percent in Finland, to 15 percent in Belgium and Germany, and to 7 percent in France), much smaller in the UK and US and even in favour of "non-natives" in Australia. Schnepf (2007) confirms these results using data from international surveys such as PISA, TIMSS and PIRLS.

The importance of language skills is highlighted also by Dustmann et al. (2010), who use UK data to compare the school performance of ethnic minority and other children from age 5 until 16. They find that, just before school entry age, ethnic minority children significantly under-perform in early cognitive tests with respect to other children. Nevertheless, they catch up during their school career, with proficiency in the English language being the single most important contributor to their progress (accounting for up to two thirds of their relative progress).

Language can be learned and findings from the economic literature show that children with an immigrant background tend to rapidly acquire proficiency in destination language skills (see Chiswich, Lee and Miller, 2007; Dustmann et al., 2010). ${ }^{15}$ In addition, many educational studies show that bilingualism is associated with a number of cognitive skills, including attention and control (see Adesope, 2010) and that bilingual children may also develop more flexibility in their thinking.

While many of these studies show that a positive correlation exists between proficiency in the host country language and educational outcomes, this correlation does not imply the presence of a causal effect. It does neither indicate that children with an immigrant background should speak the host country language at home, nor does it imply that selective policies based on the knowledge of the national language should be adopted (see Mallows, 2014).

Language skills are important also for first generation immigrants since they affect their labour market productivity. As highlighted by Bardak (2014), the education-job match is typically poor among immigrants. As discussed in a EU communication on migration (European Commission, 2011), this is partially due to the fact that in many countries foreign degrees are not recognized, which produces rents for the natives who have the same educational level as immigrants. ${ }^{16}$ The transferability of preimmigration investments in human capital, in the form of education or experience, is likely to be related to language skills: if immigrants cannot conduct a conversation in the host country language, most of

\footnotetext{
${ }^{15}$ Bleakley and Chin (2004) find that immigrants from non-English-speaking countries who arrive quite young (up until age 8 or 9) attain English-language skills comparable to those of immigrants from English-speaking countries.

16 The European Commission, 2011, emphasizes the role that can be played by policies targeted at facilitating labour mobility and job matching, including recognition of foreign qualifications and pre-departure vocational and language training.
} 
their skills cannot be used. Summarizing previous studies, Chiswick and Miller (2014) conclude that language proficiency can increase earnings of adult male immigrants by between 5 and 35 percent. ${ }^{17}$

The availability of reliable estimates of the returns to language skills is very important for evaluating the benefits of policy interventions aimed at improving immigrants' host country language proficiency. Such estimates need to address two relevant problems: selectivity and measurement error.

Consider selectivity first. An appraisal of the returns to language skills requires a comparison of different groups of immigrants, characterized by different levels of language skills. Assume that there are only two groups, one with poor skills and the other with good skills. Individuals in these two groups should differ only in their language proficiency. In practice, however, they differ also in a number of other observable and un-observable characteristics, including parental education, speed in learning and motivation. While the analyst can control for the former using standard multivariate regression analysis, less can be done for the latter. Failure to control for un-observables can lead to biased estimates. The expected bias is upwards because language proficiency is correlated to other individual characteristics that are positively valued in the labour market. For instance, immigrants with good language skills may have acquired these skills because they are hard-working individuals who are likely to provide a higher level of effort in performing their jobs compared to immigrants with poor language skills. If labour market outcomes for immigrants depend also on effort, the average observed difference in earnings between the two groups will over-estimate the returns to language skills, by assigning to these skills also the returns to effort.

On the other hand, measurement error can either be a classical measurement error - due to the interviewer reporting with error - or a systematic measurement error, due to the fact that individuals use different "scales" to assess their own language skills. In either case, this error imparts a downward bias to the estimated effect of language skills.

While much of the early literature on the returns to language proficiency has relied on the estimates of a standard earnings equation (Carliner, 1981, McManus et al., 1983, Chiswick and Miller, 1995, Dustmann, 1994), recent research has tried to address both measurement and selection problems. Dustmann and van Soest $(2001,2002)$ show that once measurement errors have been accounted for, language fluency produces a large positive effect on earnings. ${ }^{18}$ These effects survive when the selection problem is addressed using parental education as an instrument for language proficiency.

\footnotetext{
${ }^{17}$ Empirical studies considering the effects of language on earnings cover several languages, including English for the UK (Dustmann and Fabbri, 2003; Miranda and Zhu, 2013a,b), the US (Bleakley and Chin, 2004) and Australia (Chiswick and Miller, 1995), German for Germany (Dustmann, 1994; Dustmann and van Soest, 2001, 2002), Hebrew for Israel (Chiswick, 1998) and Spanish and Catalan for Spain (Budra and Swedberg, 2012; Di Paolo and Raymond, 2012).

${ }^{18}$ Dustmann and van Soest $(2001,2002)$, use panel data to distinguish between classical measurement error and timepersistent mis-classification, and show that measurement error can produce a substantial downward bias in simple OLS regressions, which might more than compensate the upward bias induced by selection.
} 
In Table 3, we present an overview of recent studies on the effects of language skills on labour market performance. Many of these studies rely on an "instrumental variables" approach (two stages least squares, or 2SLS), that uses sources of exogenous variation to identify the causal effect of language fluency for the sub-sample of the population of immigrants affected by such variation (the instrument). The instruments typically used in this literature include paternal education, a dummy for inter-marriage, the number and age of children, and measures of minority concentration. One may question, however, the validity of some of these instruments, mainly because they might also have a direct effect on labour market outcomes.

A more convincing attempt to deal with selection issues is produced by Bleakley and Chin (2004). They use census data and age at arrival as instruments for endogenous language skills. Their strategy exploits the fact that - according to many psychological studies - young children tend to learn languages more easily than adolescents and adults. Since age at arrival could affect earnings independently of language skills, they use as a control group immigrants from English-speaking countries (age at arrival should also affect their earnings but should not affect their language skills as they already speak the host country language). Consistently with the results shown by Dustmann and van Soest $(2001,2002)$, they find that OLS (ordinary least squared) estimates of the returns to language fluency are severely downward biased. Miranda and Zhu (2013b), Budra and Swedberg (2012), Di Paolo and Raymond (2012) also use age at arrival as an instrument and confirm the positive effects of host country language proficiency on labour market outcomes. Yao and van Ours (2015) use data from the Netherlands and consider deficiencies in Dutch language skills (they use as an instrument the age at arrival interacted with a dummy variable for whether one grew up speaking Dutch). They find some negative effects on female immigrants (on hourly wages but not on employment probability and hours of work) and no effects on male immigrants. These results might depend on the type of jobs that men and women do: while females are more likely to be employed in sectors where language proficiency is important, males are more likely to be engaged in manual work and operate in industries where communication in Dutch is not very relevant.

Bleakley and Chin (2010) use the same identification strategy used in their previous paper (Bleakley and Chin, 2004) to estimate the effects of language proficiency on a number of social outcomes. Focusing on US immigrants, they find that English proficiency increases the probability of marrying a US native and of choosing spouses who have higher education and better labour market outcomes. English-language skills affect both fertility and the probability of divorcing, reducing the former and increasing the latter. Residential location outcomes are affected too, as English proficiency reduces enclave residence.

Overall, these results underline the importance of language skills for the integration of immigrants and point to the fact that the challenges faced by European countries in integrating these immigrants 
might be different. For geographical and historical reasons, European countries show marked differences in the percentage of immigrants who speak the receiving country language. While receiving countries characterized by a high share of immigrants who already speak the local language are likely to face lower integration costs, countries where there is a large share of immigrants who do not speak the host country language might incur higher costs. Linguistic distance also matters, as it is easier for a foreigner to acquire a language if his/her native language is linguistically closer to the language to be learned (Chiswick and Miller, 2005; Isphording and Otten, 2011). In addition, as shown by Dustmann and Glitz (2011), parents and second generation children might be more motivated to supply effort and learn a language that is valuable in multiple locations. While widespread languages, such as English, have a high value in all alternative locations and their acquisition represents a general investment, less common languages have a high value only in the host country and individuals who have to invest to learn them face the typical disincentives associated to specific investments that have limited or no transferability.

Table 3. Studies on language skills and labour market performance

\begin{tabular}{|c|c|c|c|c|}
\hline Authors & Focus of the Analysis & Data & $\begin{array}{c}\text { Estimation } \\
\text { Method }\end{array}$ & Magnitude of the Estimated effects \\
\hline $\begin{array}{l}\text { Dustmann } \\
\text { (1994) }\end{array}$ & $\begin{array}{l}\text { German proficiency } \\
\text { on earnings in } \\
\text { Germany (males and } \\
\text { females) }\end{array}$ & $\begin{array}{l}\text { Cross-sectional } \\
\text { Data of immigrants } \\
\text { from GSOEP } \\
\text { survey }\end{array}$ & $\begin{array}{l}\text { OLS with } \\
\text { Heckman } \\
\text { selection }\end{array}$ & $\begin{array}{l}\text { Speaking proficiency in German on } \\
\text { earnings: } \\
-7 \% \text { (Males })-15 \% \text { (Females) }\end{array}$ \\
\hline $\begin{array}{l}\text { Chiswick and } \\
\text { Miller } \\
(1995)\end{array}$ & $\begin{array}{l}\text { English fluency on } \\
\text { earning in Australia }\end{array}$ & $\begin{array}{l}\text { Cross-sectional data } \\
\text { of male immigrants } \\
\text { from } 1981 \text { and } 1986 \\
\text { Census of Australia }\end{array}$ & $\begin{array}{l}\text { OLS and } \\
\text { 2SLS }\end{array}$ & $\begin{array}{l}\text { English fluency on earning: } \\
\text { OLS: }-5 \% \text {, } \\
\text { 2SLS: }-24 \% \text { statistically insignificant }\end{array}$ \\
\hline $\begin{array}{l}\text { Chiswick } \\
\text { (1998) }\end{array}$ & $\begin{array}{l}\text { Hebrew usage on } \\
\text { male earnings in Israel }\end{array}$ & $\begin{array}{l}\text { Cross-sectional data } \\
\text { of male immigrants } \\
\text { from } 1983 \text { Israel } \\
\text { Census }\end{array}$ & $\begin{array}{l}\text { OLS and } \\
\text { 2SLS }\end{array}$ & $\begin{array}{l}\text { Hebrew as a primary language on earning: } \\
\text { OLS: }-11 \% \\
\text { 2SLS: }-35 \%\end{array}$ \\
\hline $\begin{array}{l}\text { Dustmann and } \\
\text { van } \\
\text { Soest (2001) }\end{array}$ & $\begin{array}{l}\text { Effect of German } \\
\text { fluency on male } \\
\text { earnings in Germany }\end{array}$ & $\begin{array}{l}\text { Panel data of male } \\
\text { immigrants from } \\
\text { GSOEP survey }\end{array}$ & $\begin{array}{l}\text { Ordered } \\
\text { probit, } \\
\text { simultaneo } \\
\text { us } \\
\text { equations } \\
\text { for mis- } \\
\text { specificatio } \\
\text { n error; } \\
\text { random } \\
\text { effects } \\
\text { for } \\
\text { unobserved } \\
\text { heterogenei } \\
\text { ty }\end{array}$ & $\begin{array}{l}\text { Speaking fluency in German on earnings: 0.9- } \\
7.3 \%\end{array}$ \\
\hline $\begin{array}{l}\text { Dustmann and } \\
\text { van } \\
\text { Soest (2002) }\end{array}$ & $\begin{array}{l}\text { Effect of German } \\
\text { skills on male and } \\
\text { female earnings in } \\
\text { Germany }\end{array}$ & $\begin{array}{l}\text { Panel data of } \\
\text { immigrants from } \\
\text { GSOEP survey }\end{array}$ & $\begin{array}{l}\text { OLS and } \\
2 S L S\end{array}$ & $\begin{array}{l}\text { Speaking fluency in German on earnings: } \\
\text { OLS: }-5 \% \text { for men and }-4 \% \text { for women, } \\
\text { 2SLS: } \\
-14 \% \text { for men and }-12 \% \text { for women }\end{array}$ \\
\hline $\begin{array}{l}\text { Dustmann and } \\
\text { Fabbri } \\
\text { (2003) }\end{array}$ & $\begin{array}{l}\text { Effect of English skills } \\
\text { on } \\
\text { employment }\end{array}$ & $\begin{array}{l}\text { Cross-section data } \\
\text { of immigrants from } \\
\text { Fourth National }\end{array}$ & $\begin{array}{l}\text { OLS and } \\
\text { Propensity } \\
\text { score }\end{array}$ & $\begin{array}{l}\text { English speaking on employment probability } \\
\text { and earnings: } \\
\text { OLS: }\end{array}$ \\
\hline
\end{tabular}




\begin{tabular}{|c|c|c|c|c|}
\hline & $\begin{array}{l}\text { probability and } \\
\text { earnings in UK (males } \\
\text { and females) }\end{array}$ & $\begin{array}{lr}\text { Survey on } & \text { Ethnic } \\
\text { Minorities (FNSEM) } \\
\text { and Family } r \text { and } \\
\text { Working } & \text { Lives } \\
\text { Survey } & \text { (FWLS) } \\
\text { surveys } & \end{array}$ & estimator & $\begin{array}{l}\text { Employment probability: }-19 \text { p.p. for males } \\
\text { and no effects for females using FWLS and - } \\
17 \text { p.p. for both males and females using } \\
\text { FNSEM } \\
\text { Earnings: }-17 \% \text { for both males and females } \\
\text { using FWLS and }-12 \% \text { for males and }-35 \% \text { for } \\
\text { females using FNSEM. } \\
\text { Propensity score matching: } \\
\text { Employment probability: } \\
-10 \text { p.p. for males and }-11 \text { p.p. for females } \\
\text { using FWLS } \\
-10 \text { p.p. for males and }-13 \text { p.p. for females } \\
\text { using FNSEM. } \\
\text { Earnings: }-24 \% \text { for males and } 46 \% \text { for } \\
\text { females using FWLS } \\
\text { Propensity matching with IV accounting for } \\
\text { measurement error: } \\
\text { Employment probability: } \\
-26 \text { p.p. for males and }-14 \text { p.p. for females } \\
\text { using FNSEM } \\
\text { Earnings: large but weakly or not statistically } \\
\text { significant effects }\end{array}$ \\
\hline $\begin{array}{l}\text { Bleakley and } \\
\text { Chin } \\
(2004)\end{array}$ & $\begin{array}{l}\text { Effect of English } \\
\text { proficiency on } \\
\text { earnings in US }\end{array}$ & $\begin{array}{l}\text { Cross-sectional data } \\
\text { of child immigrants } \\
\text { from US Census } \\
1990\end{array}$ & $\begin{array}{l}\text { OLS and } \\
2 \text { SLS }\end{array}$ & $\begin{array}{l}\text { English proficiency on earning: } \\
\text { OLS: }-22 \% \text {, } \\
\text { 2SLS: }-33 \%\end{array}$ \\
\hline $\begin{array}{l}\text { Bleakley and } \\
\text { Chin } \\
(2010)\end{array}$ & $\begin{array}{l}\text { Effect of English } \\
\text { proficiency on social } \\
\text { assimilation in US }\end{array}$ & $\begin{array}{l}\text { Cross-sectional data } \\
\text { of child immigrants } \\
\text { from US Census } \\
2000\end{array}$ & $\begin{array}{l}\text { OLS and } \\
2 \text { SLS }\end{array}$ & $\begin{array}{l}\text { Immigrants with better English proficiency } \\
\text { have more education, higher earnings, higher } \\
\text { chance of intermarriage, fewer children, } \\
\text { higher probability of divorce and lower } \\
\text { chance of living in ethnic enclaves. } \\
\text { OLS effects are smaller in magnitude } \\
\text { compared to 2SLS effects. }\end{array}$ \\
\hline $\begin{array}{l}\text { Budria and } \\
\text { Swedberg } \\
(2012)\end{array}$ & $\begin{array}{l}\text { Spanish proficiency } \\
\text { on earnings in Spain }\end{array}$ & $\begin{array}{l}\text { Cross-sectional data } \\
\text { of male } \\
\text { immigrants from } \\
\text { Spanish National } \\
\text { Immigrant Survey } \\
\text { (Encuesta Nacional } \\
\text { de Inmigrantes) }\end{array}$ & $\begin{array}{l}\text { OLS and } \\
\text { 2SLS }\end{array}$ & $\begin{array}{l}\text { Spanish proficiency on earning: } \\
\text { OLS: }-5 \% \\
\text { 2SLS: }-27 \%\end{array}$ \\
\hline $\begin{array}{l}\text { Di Paolo and } \\
\text { Raymond } \\
(2012)\end{array}$ & $\begin{array}{l}\text { Catalan proficiency on } \\
\text { earnings in Catalonia }\end{array}$ & $\begin{array}{l}\text { Cross-sectional data } \\
\text { of immigrants from } \\
\text { EHCV06 survey }\end{array}$ & $\begin{array}{l}\text { OLS, } \\
\text { endogenou } \\
\text { s switching } \\
\text { model and } \\
\text { 2SLS }\end{array}$ & $\begin{array}{l}\text { Catalan proficiency on earnings: } \\
\text { OLS: } 7 \% \\
\text { endogenous switching model: } 16 \% \\
\text { 2SLS: } 16 \%\end{array}$ \\
\hline $\begin{array}{l}\text { Miranda and } \\
\text { Zhu } \\
(2013 a)\end{array}$ & $\begin{array}{l}\text { English deficiency on } \\
\text { immigrant-native wage } \\
\text { gap for female } \\
\text { employees in the UK }\end{array}$ & $\begin{array}{l}\text { Cross-sectional data } \\
\text { of female } \\
\text { immigrants from } \\
\text { UK Household } \\
\text { Longitudinal Survey } \\
\text { (UKHLS) }\end{array}$ & $\begin{array}{l}\text { OLS and } \\
\text { Three-step } \\
\text { estimation } \\
\text { procedure } \\
\text { (TSEP, or } \\
\text { 2SLS } \\
\text { accounting } \\
\text { for } \\
\text { selection in } \\
\text { employmen } \\
\text { t) }\end{array}$ & $\begin{array}{l}\text { English no first language on wages: } \\
\text { OLS: }-19 \% \text {, } \\
\text { TSEP: }-25 \% \text {, }\end{array}$ \\
\hline $\begin{array}{l}\text { Miranda and } \\
\text { Zhu } \\
(2013 b)\end{array}$ & $\begin{array}{l}\text { English deficiency on } \\
\text { immigrant-native } \\
\text { wage gap for male } \\
\text { employees in the UK }\end{array}$ & $\begin{array}{l}\text { Cross-sectional data } \\
\text { of immigrants from } \\
\text { UK Household } \\
\text { Longitudinal Survey }\end{array}$ & $\begin{array}{l}\text { OLS and } \\
2 \text { SLS }\end{array}$ & $\begin{array}{l}\text { English no first language on wages: } \\
\text { OLS: }-16 \% \text {, } \\
\text { 2SLS: }-23 \%\end{array}$ \\
\hline
\end{tabular}




\begin{tabular}{|c|c|c|c|c|}
\hline & & (UKHLS) & & \\
\hline $\begin{array}{l}\text { Yao and van } \\
\text { Ours (2015) }\end{array}$ & $\begin{array}{l}\text { Dutch proficiency on } \\
\text { employment, } \\
\text { hours of work and } \\
\text { wages in the } \\
\text { Netherlands }\end{array}$ & $\begin{array}{l}\text { Longitudinal } \\
\text { Internet Studies for } \\
\text { the Social } \\
\text { Sciences (LISS) } \\
\text { panel survey }\end{array}$ & $\begin{array}{l}\text { OLS and } \\
\text { 2SLS }\end{array}$ & $\begin{array}{l}\text { Language problems } \\
\text { OLS: } \\
\text { Probability of being employed - }-12.5 \text { p.p. for } \\
\text { females no significant effects for males } \\
\text { Hours of work } \\
\text { No statistically significant effects neither for } \\
\text { females nor for males } \\
\text { Hourly wages } \\
\text { No significant effects for females, - 13.8\% for } \\
\text { males. } \\
2 \text { SLS: } \\
\text { Probability of being employed } \\
\text { No statistically significant effects for both } \\
\text { females and males } \\
\text { Hours of work } \\
\text { No statistically significant effects for both } \\
\text { females and males } \\
\text { Hourly wages } \\
\text { - } 47 \% \text { for females; no statistically significant } \\
\text { effects on males }\end{array}$ \\
\hline
\end{tabular}

Notes: Yao and van Ours, 2015, provide a similar table. OLS: ordinary least squares; 2SLS: two stages least squares.

One should also consider that competencies in several languages, as shown by a number of psychological studies, might enhance the ability to learn and generate intercultural benefits. Unfortunately, the economic literature on this topic is scant. An interesting paper in this area is LlerasMuney and Shertzer (2015), who show that a number of laws adopted in the US between 1910 and 1930 - making English the sole language of instruction in schools - has had only modest effects on the educational achievement of children with an immigrant background, in stark contrast with the sizeable effects produced by compulsory schooling laws. Slavin et al. (2010) also find no difference in the English language skills of students randomly assigned to either bilingual or English immersion programs. Comparable results are reported by Matsudaira (2005) and Chin, Daysal and Imberman (2012) when studying the effects of bilingual education.

Overall, the evidence reviewed in this section suggests that policies aimed at supporting language learning and the acquisition of new skills in the host country are likely to be particularly useful, while limited effects should be expected from policies imposing the exclusive use of the host country language in schools. Similar conclusions are reached by a report recently produced by the European Commission (2015), investigating which policies are beneficial to the educational outcomes of immigrant children who use a different language at home from the one used at school. This report refers both to the academic literature and to the experience and competencies of practitioners and recommends: a) the provision of extra-funds to schools in order to help children learning the language of instruction; b) train teachers to deal with children who lack competence in the language of instruction and to prepare them to work in a multilingual classroom environment; c) support out-ofschool activities and the engagement of parents. It also reviews policies adopted in EU Member States 
to support learning both of the host country language and of the mother tongue and discusses evidence on the impact of these policies. While evaluation studies are rare, there is suggestive evidence showing that the inclusion of immigrant children who lack competencies in the language of instruction in mainstream classrooms (with support of properly trained teachers and specialists) gives better results than preparatory teaching in separate classes (Nusche, 2009). In addition, Clair et al. (2012) show that training programs involving parents have positive effects on student performance. Their evidence originates from an experimental setting that addresses the self-selection of parents in the program but is based on a very small sample (50 children). Clearly, additional work is needed to better understand the costs and benefits of different policies.

\section{Educational achievement of immigrant children and school organization}

A well-established literature in labour economics has examined how the effect produced by socioeconomic status on educational achievement is mediated by institutional features of the educational system. In a similar vein, a number of recent papers have investigated whether the educational outcomes of immigrant children are affected by the institutional design of national educational systems, including pre-school attendance, school tracking and the combination of students and teacher characteristics.

Entry in the pre-school system is a crucial moment for children in general since they start to spend time outside the family and become exposed to new stimuli. For immigrant children, this moment is even more important, because for some of them it might represent the first opportunity of systematic interactions with native children and supervision by teachers in the host country. These interactions are key for the acquisition of the cultural habits of the host country and are also important for language development. Therefore, providing children with an immigrant background with adequate access to pre-school services might be a sensible policy to improve their long-term educational outcomes.

Again, the identification of the causal effect of pre-school attendance on school outcomes is not straightforward, because the decision to send children to pre-school is typically associated to unobserved factors that also affect the educational outcomes of children. Some papers have tried to deal with this issue by relying on natural experiments, such as the introduction either of universal preschool systems or of free pre-school for some population groups. This literature finds beneficial effects of attendance for girls and children from disadvantaged families (Cascio 2009, Havnes and Mogstad, 2009, Berlinski et al. 2009, Melhuish et al. 2004, Cambellet al. 2002, Anderson 2008).

Few studies have investigated the impact of pre-school attendance on children with an immigrant background or belonging to minority groups. In the US context, Gormley et al. (2005) and Gormley 
and Gayer (2008) have investigated the impact of the Oklahoma universal pre-kindergarten program, showing that participation in this program is associated with larger gains for children of immigrant families with low education. In the European context, Drange and Telle (2015) have analysed the introduction of a free pre-school program targeting five-years-olds in two districts of Oslo. They use a difference-in-differences approach, taking advantage of the fact that the intervention has been implemented only in two districts, leaving other similar districts unaffected. They focus on the school performance of children with an immigrant background ten years after the program and find beneficial effects on girls, but not on boys.

Dustmann, Raute, and Schoenberg (2013) analyse the impact of a staggered expansion in child care facilities in German municipalities and find that longer public child care attendance alleviates language and motor skill problems and improves school readiness for children with an immigrant background. Finally, Felfe and Huber (2015) exploit individual distance to the nearest facility as an instrument for pre-school attendance (controlling for household and neighbourhood characteristics and for regional fixed effects) to study its effects on the educational outcomes of Roma children. They find positive returns in terms of both verbal and analytical skills.

A discussion of the benefits deriving from participation in early childhood education for immigrant children is also provided in a European Commission report (2015). This document relies both on studies from different fields (economics, education and psychology) and on practitioners' views and recommends policies facilitating access to early education and policies that foster child care for children with an immigrant background. These policies have been experimented with in the Netherlands via the Opstapje project, targeted at 2-4 year old children with the aim of strengthening their cognitive, social and physical competences and their learning of the language of instruction (European Commission, 2015).

Another school feature that might influence the educational attainment of second generation immigrants is school tracking, or the differentiation of school curricula into vocational and academic tracks. Education systems in Europe differ in the age at which students are tracked into different types of education. While in Scandinavia and the UK secondary schools are broadly comprehensive, in Austria, Germany, The Netherlands and the Czech Republic pupils need to choose the relevant track quite early in their education career. The age at which students are tracked into different types (or levels) of education has been found to affect equality of opportunities in education, by reinforcing the effects of socio-economic family background on educational outcomes (Hanushek and Wößmann, 2005; Brunello and Checchi, 2007; Schütz et al., 2008, Pekkarinen et al., 2009).

Early selection into tracks might also affect the educational attainment of children with an immigrant background, because these students in Europe not only are typically from a disadvantaged background but also face difficulties due to poor control of the host country language, that is likely to 
be particularly relevant at younger ages. In the countries where selection by ability prevails, the failure to discriminate between language difficulties and learning abilities may increase the enrolment of immigrants in the more vocationally oriented tracks that often do not lead to higher education (see European Commission 2015). These aspects might suggest that early tracking has detrimental effects on the immigrant-native educational gaps and that the adoption of comprehensive educational systems may improve the educational opportunities of immigrants.

In spite of the importance of the issue, the effect of early selection on immigrant students has been investigated only rarely and with mixed results. Lüdemann and Schwerdt (2013) argue that early tracking of youths in the school system can represent a barrier for immigrants since tracking takes place before the acquisition of good language skills. Yet, they find that inequalities among children of native parents and children with an immigrant background at the transition to secondary school are due to socio-economic background rather to a negative penalty associated with migratory status.

Evidence on the relationship between educational tracking and immigrants' relative achievement that uses cross-sectional data is provided by Cobb-Clark et al. (2012). However, cross-sectional estimates are plagued with endogeneity problems, mainly because of selective migration into countries with different school systems. For instance, late tracking countries such as United States, Australia, Canada, New Zealand and United Kingdom are characterized by a relatively well-educated population of immigrants (also because of their highly selective migration policies), whereas early tracking countries such as Germany, Austria, the Netherlands and Belgium attract less educated immigrants (their immigration policies typically favour refugees or family reunification), suggesting that the uncovered correlation between tracking and the education of immigrants may be driven by differences in country-specific immigration policies.

An interesting study trying to overcome this problem is Ruhose and Schwerdt (2013). They pool data from PISA, TIMSS, and PIRLS (providing internationally comparable information on students' proficiency in reading, math, and science $)^{19}$ and analyse the impact of tracking on "migrant-native" test score gaps using both a standard multivariate regression model and a difference-in-differences approach. Their OLS estimates show that early educational tracking produces negative effects on the test scores of children with an immigrant background (in all subjects). After controlling for individual and country specific characteristics, however, the estimated effects shrink in absolute terms to $13 \%$ of a standard deviation in reading, $11 \%$ of a standard deviation in math, and $10 \%$ of a standard deviation (not statistically significant) in science.

As discussed above, these results do not provide evidence that the tracking system has a causal effect on the relative performance of second generation immigrants, because early and late tracking

\footnotetext{
${ }^{19}$ Their dataset covers one million students from 45 countries.
} 
countries might be characterized by unobserved features that systematically affect the relative performance of immigrant students with respect to their native peers. To overcome this problem, Ruhose and Schwerdt use a difference-in-differences estimation strategy that uses information on students' performance during primary school, when no country tracks students. The effects of early tracking are identified by using both the variation in "immigrant-native" test score gaps between primary and secondary school and the variation in the age of tracking among countries.

Their estimates show that a negative "immigrant-native" achievement gap already exists in the primary schools of early tracking countries, which points to an upward bias in the effects estimated using ordinary least squares (OLS). Not surprisingly, their difference-in-differences estimation shows no significant effects of early tracking. Yet they also find that results vary according to whether immigrant students speak the language of the test at home. For immigrant students who almost never speak the test language at home, their evidence indicates the presence of a large and significant negative effect of early school tracking on reading test scores (but not on math and science scores). An important policy implication of these findings is that, while in general late tracking does not help to reduce the immigrant-native gap, it might be useful for children from less integrated families, who lack proficiency in the national language. However, it is important to emphasize that language proficiency is likely to be affected by unobservable socio-economic variables and individual characteristics. These unobservable features might then represent the effective reason why school tracking has the observed differential effect.

An additional factor that might affect the school performance of students with an immigration background is the combination of teacher and student demographic characteristics. Teachers could change their behaviour in class in reaction to students' migratory status with consequences on performance. For instance, teachers might have stereotyped expectations on students' skills, which might result in a self-fulfilling prophecy: $:^{20}$ Teachers might demand less effort of minority students or give them less feedback, praise them less often for success and criticize them more frequently for failure, and these students might lose motivation and self-confidence as a consequence. On the other hand, students might change their behaviour in relation to their teacher's demographic characteristics, in spite of the fact that the teacher's behaviour is unchanged by their immigrant status. As discussed by Dee (2005), same-ethnicity teachers, for example, might improve performance by serving as a role model for minority students, while having a teacher of a different ethnicity might lead students to misbehave.

\footnotetext{
${ }^{20}$ This is nicely documented in the well-known psychological study conducted by Rosenthal and Jacobson, (1968), where they show that the randomly allocated students' IQ, communicated to teachers at the beginning of the year, affected student performance at the end of the year.
} 
Some evidence on this issue comes also from two studies focusing on tertiary education. Fairlie et al. (2011) use administrative data from a large community college in the United States to study the extent to which academic performance depends on students having the same ethnicity as their instructors. Using an estimation strategy that controls for student and classroom characteristics (fixed effect method) to deal with endogenous sorting, they find that the minority achievement gap is smaller when minority students are taught by a "minority instructor". Minority students improve their performance in terms of better grades, dropping out behaviour, probability of taking subsequent courses in the same subject, major choice, retention and overall attainment. More mixed results are found by Lusher et al. (2015), who use data from a university in California and analyse whether the academic outcomes of undergraduates are affected by the ethnicity of their graduate student teaching assistants (TAs). As TAs are assigned to courses after students' enrolment, selection is not a matter of concern in this setup. Results show a positive and significant increase in course grades when students are assigned TAs of a similar ethnicity. Some of the improved academic performance seems to be related to student behaviour, since assignment to TAs of the same ethnic group positively affect attendance to both discussion sections and office hours.

Changes in teacher behaviour and expectations are found also in other related research. Dee (2005), for instance, shows that teachers tend to rate substantially worse the behaviour in class of students belonging to different ethnicity than that of students belonging to their own ethnic group, which might reflect either teachers' perceptions or students' behaviour.

Using data on a representative sample of students from public Swedish high schools who were tested on a core subject (Swedish), Hinnerich et al. (2014) find evidence of a sizeable and robust discrimination by teachers against students with a foreign background. In a similar fashion, Kiss (2013) finds evidence that second-generation immigrants in Germany are affected by grade discrimination in primary education because, conditional on skills, their grades are substantially lower than average. No such evidence exists, however, for secondary and upper-secondary education. Evidence of bias in grading practices is found also by Lindahl (2007) and Burgess and Greaves (2009), for Sweden and England respectively. They show that teachers give ethnic minority students assessments that deviate from what would be expected based on national standardized tests. ${ }^{21}$

In an attempt to disentangle more clearly between grading biases and differences in skills acquisition (induced by teacher-students interaction) Van Ewijk (2011) runs a field experiment in which any effect that might derive from changes in students behaviour is removed. By manipulating the names of students, who had the task of writing essays, teachers working in the Netherlands were induced to

\footnotetext{
${ }^{21}$ These papers rely on the implicit assumption that the "majority" group's outcome is the norm while the "minority" group is discriminated against. However, it could also be that the majority group is favoured while the minority group's outcome is the norm. Feld, Salamanca, and Hamermesh (2013) distinguish between favouritism and discrimination. Using a randomized field experiment, they find evidence of favouritism but not of discrimination in grading.
} 
believe that some essays were written by Dutch students while others were written by Turkish or Moroccan students. Results show that - on average - teachers do not exhibit a grading bias. On the other hand, there is evidence that ethnic majority teachers have lower expectations on children belonging to ethnic minorities. For instance, they expect minority students to be more likely to end up in vocational tracks than similar students belonging to the ethnic majority. In addition, teachers report relatively unfavourable attitudes toward minority students.

In contrast, using a similar experiment in which German and Turkish names are randomly assigned to sets of essays written by fourth-graders, Sprietsma (2009) provides evidence supporting the presence of grade discrimination in primary education in Germany. She finds that essays with Turkish names obtain significantly lower grades. The size of the effect is relatively small (about $10 \%$ of a standard deviation). In addition, teachers recommend enrolment in the academic track of secondary school with a 10\% lower probability when an essay bears a Turkish name.

Overall, these results suggest that it might be beneficial to change stereotyped attitudes held by teachers, for instance using targeted training programs, and increase awareness that these attitudes might negatively affect students' performance. ${ }^{22}$ A number of programs implemented in some EU Member States involve the provision of training for teachers in order to enable them to incorporate cultural diversity within their teaching (European Commission 2015). The recruitment of teachers with an immigration background or belonging to ethnic minorities might also be useful. As shown by the literature reviewed above, the lack of immigrant teachers might impose severe restrictions on the availability of role models and increase the possibility of "stereotyped threats" and discrimination against students with an immigrant background. The "stereotyped" perceptions of teachers might also play a role in explaining why immigrant children are over-represented in special education and lower ability tracks.

The results found by the literature reviewed in this section can be summarized by pointing out that, while pre-school attendance and positive role models of teachers are beneficial for immigrant children, late tracking seems to produce positive effects only for children who lack proficiency in the national language. Another factor that might affect the performance of both children with immigrant background and children of native parents is the share of non-native peers in the class or school. We consider this issue in the next section.

\footnotetext{
${ }^{22}$ The evaluation of the magnitude of the "discrimination" effects found in the literature in comparison to other factors such as socio-economic background and language proficiency is not straightforward. Some studies find large effects in comparison to those deriving from socio-economic status (for instance Kiss, 2013, and Dee, 2005) while others find much smaller effects (Sprietsma, 2009).
} 


\section{Migrants and the educational outcomes of children with native parents}

The segregation of students with an immigrant background into different schools is an important issue in the debate focusing on educational integration. Class composition can affect both natives and immigrants' educational outcomes. In many countries schools and classes are characterized by a high proportion of pupils who do not speak the language of assessment at home (OECD, 2013). In principle, there are advantages and disadvantages from segregation. On the one hand, grouping together students from an immigrant background might allow teachers to adopt a teaching style that fits well with the specific needs of these students and produce positive effects on their educational outcome as a consequence. In addition, since it is plausible to think that these students need special attention from teachers, teaching could be organized in smaller classes. On the other hand, segregation is likely to hamper social interaction with children of native parents, with negative effects on language skill acquisition and social integration. This is because pupils receive important inputs from their schoolmates for the development of their skills. The effects, originating from interactions that are taking place among schoolmates, are commonly referred to as 'peer effects'. Education economists have highlighted, both in theoretical and empirical studies, the relevance of peer effects for student performance. A peer group affects student achievement in several ways. For instance, members of a group interact in learning, help each other in their studies, share important information, impose externalities on others by behaving well or badly (for example, a noisy student disrupts the study environment) or by allowing teachers to go more deeply into subjects, contribute to the formation of values and aspirations, and so on.

Starting from the classical study by Coleman et al. (1966), a host of papers have analysed the effects of the peer group on children's achievement and educational outcomes. Nevertheless, the specific question of whether class composition, in terms of ethnic characteristics, affects the educational outcomes of children with either a native or an immigrant background has received relatively little attention. So far, the evidence on this issue is rather mixed.

Understanding the nature and the magnitude of peer group effects in education is crucial for school design. Systems in which classes are totally segregated according to ethnicity might be efficient when there are strong negative spill-over effects from children with an immigrant background to children of native parents and no positive effects in the opposite direction. On the other hand, having mixed classes might be optimal if spill-overs are positive or null. The optimal class composition depends also on whether peer effects are linear or not. In fact, spill-overs associated to the share of children with an immigrant background in the class might not be constant, and their effects might increase (or decrease) as the proportion of immigrants becomes larger. If for sufficiently low values of the immigrant share 
there are no sizeable negative impacts on children of native parents, it can be optimal to avoid concentration of immigrant students in the same class.

Earlier analyses of peer effects were based on simple econometric models regressing students outcomes on their own individual characteristics (measures of ability, family background and so on) and on their peers' outcomes or characteristics. However, these regressions are plagued by serious selection bias, due to the fact that peers are chosen, not assigned randomly. The characteristics of each student are correlated with those of his/her peers, implying that student characteristics are relevant both for their educational outcomes and for the definition of their peer group. Since some of these characteristics are unobservable, they cannot be controlled for in standard multivariate regression analysis, leading to an endogeneity problem.

In the case of immigrants, the selection problem derives from the fact that they typically locate in poorer areas and, as a consequence, their children typically attend schools that are attended by lowerachieving native students. In addition, given the residential decision, families might have some degree of freedom in school choice and select a school on the basis of expected peer characteristics and perceived quality. For instance, Betts and Fairlie (2003) show that when additional immigrants arrive in public high schools, children of native parents tend to switch to a private school ("native flight phenomenon"). Finally, the allocation of immigrant students among classes is typically not random, but decided by the school administration.

These sorting processes may generate either a downward or an upward bias in peer effects estimates. On the one hand, the sorting of immigrant students in schools attended by students of native background who have low unobserved ability leads to an overestimation of the potential negative effect of immigrant students on their native peers, because of the negative spurious correlation between the attainment level of native students and the share of immigrant students in the school. On the other hand, we are likely to observe a downward bias in these estimates if school administrators tend to assign immigrant pupils to better teachers or to smaller classes.

The recent economic literature investigating peer effects has adopted four main different identification strategies. The first approach relies on events or experiments that generate random assignment of peers to a class or school. The second approach uses instrumental variables ${ }^{23}$ to remove the correlation between individual unobserved characteristics and peer characteristics. The third approach relies on aggregation procedures (to city, metropolitan area and school level) to circumvent the bias generated by selection issues, and the fourth approach uses fixed effects models. The literature investigating how peer effects influence the relationship between native and immigrant students has

\footnotetext{
${ }^{23}$ By instrumental variables (or instruments) we mean variables that affect class composition but are not correlated with the outcome of interest.
} 
relied mainly on the last three approaches. Depending on the different socio-economic context, studies have focused on the achievement gaps either between minority and majority students (mainly in the US) or between children with an immigrant background and children of native parents (mainly in Europe).

While our focus is mainly on Europe, we also consider some evidence from the US: students from minority ethnic groups might share some significant features with immigrant students, for instance in terms for cultural diversity.

The most significant recent contributions for the US are Hoxby (2000), Hanushek and Rivkin (2009), Hanushek et al. (2009), Friesen and Krauth (2011) and Cooley (2013). Hoxby (2000) uses the variation in the ethnic composition among cohorts within schools and finds that the share of black students in a class has weak effects on the performance of white students, but a negative impact on the test scores of black students. The estimated negative effect is about four times larger for black students than for white students. Hanushek and Rivkin (2009), Hanushek et al. (2009) and Cooley (2013) also find that peer effects within the immigrant group are stronger than the effects on children of native parents. Conversely, Friesen and Krauth (2011) study the effects of the language spoken by students at home on their attainment and find that the 'within-group' effects ${ }^{24}$ are weaker when compared to 'across-groups' effects ${ }^{25}$. We conclude that findings based on the US are ambiguous as regards the importance of the linguistic and ethno-cultural similarity to peers for individual educational outcomes.

The impact of immigrant concentration on the academic achievement of European students has been analysed in few studies. Some papers (Brunello and Rocco, 2011, Ballatore et al., 2013, Tonello, 2015) focus exclusively on the effects of the share of pupils with an immigrant background on native students, while other papers (Jensen and Rasmussen, 2011; Ohinata and VanOurs, 2013; Contini, 2013; Schneeweis, 2015) investigate also the impact of this share on students with immigrant background.

Results are mixed. As summarized in Table 4, the estimated negative effects of the share of immigrants on children of native parents range from significant in Gould et al. (2009) and Ballatore et al. (2013) to small in Brunello and Rocco (2013) and Tonello (2015) and to virtually zero in Geay et al. (2013), Ohinata and Van Ours (2013), Contini (2013) and Schneeweis (2015). While Jensen and Rasmussen (2011) find negative effects of ethnic concentration on both native and immigrant students, Ohinata and Van Ours (2013), Contini (2013) and Schneeweis (2015) find no sizeable effect on native students and negative effects on immigrant students.

Quasi experimental evidence is provided by Gould et al. (2009) and Geay et al. (2013). Gould et al. (2009) analyse the impact of immigrant concentration during elementary school on the long-term academic outcomes of students with a native background following the mass migration wave from the

\footnotetext{
${ }^{24}$ The effects produced by minority students on students from minority ethnic groups.

${ }^{25}$ The effects produced by minority students on majority students.
} 
former Soviet Union to Israel in the early 1990s. Their identification strategy is based on the assumption that, conditional on the total number of immigrant students admitted to a given school, the variation in the proportion of "immigrants" across grades of the same school can be considered as solely due to exogenous demographic factors. They find large negative effects of the share of “immigrants" on native students.

Contini (2013) and Ohinata and Van Ours (2013) address the problem of the endogenous sorting of children with an immigrant background between schools by exploiting the variability in the share of immigrant students within schools between classes of a given grade. This approach is based on the assumption that, once school fixed effects are controlled for, the allocation of children with an immigrant background between classes is as good as random. Using Italian data, Contini (2013) reports that the share of children with an immigrant background in the class has weak negative effects on the test scores of children of native parents but larger negative effects on the children of immigrants. No adverse effects of the share of children with an immigrant background on children of native parents are found also by Ohinata and Van Ours (2013), who look at Dutch data using repeated waves from PIRLS and TIMSS. They find evidence that the share of children with an immigrant background has negative effects on the reading scores of immigrant students.

Ballatore et al. (2014) argue that identification strategies based on within-school variation in the share of students with an immigrant background might lead to biased results because of the class size adjustments implemented by school administrators who fear disruption effects from immigrant children. Once this source of bias is taken into account, they find adverse consequences of immigrant concentration for children of native parents.

An alternative approach that uses the variability in ethnic composition between adjacent cohorts within the same school is used by Tonello (2015) and Schneeweis (2015). This approach is based on the assumption that the variability between subsequent cohorts is random when the data are aggregated at the school-cohort level. Tonello (2015), who uses administrative data covering the census of Italian junior high schools, finds a weak negative impact of the share of students with an immigrant background on the test scores of native peers. Interestingly, the effects are nonlinear and increasing with the share of students with an immigrant background in the school, suggesting that a problem may arise only for relatively high shares. These results are supportive of policies that introduce caps in the share of immigrant children in a class and of other policies that may reduce segregation. Policies of this type have been introduced in Denmark and Belgium with the objective of alleviating the pressure faced by some schools and/or increasing social and cultural integration.

Schneeweis (2015) does not focus on test scores but considers as outcome variables grade repetition in primary and secondary Austrian schools and track attendance after primary education. She finds that while students from a native background are not affected by the share of students with an immigrant 
background, students with an immigrant background are negatively affected by immigrant concentration. The negative spill-over effects are particularly strong for students of the same ethnic group.

Jensen and Rasmussen (2011) rely on school fixed effects and instrument immigrant concentration in class using the ethnic concentration in the geographical area where each school is located. Using this identification strategy, they investigate the effect of immigrant concentration on the PISA test scores of $9^{\text {th }}$ grade students in Denmark. Results show that there is a negative effect of ethnic concentration on both native and immigrant students.

Geay et al. (2013) also implement a 2SLS estimation strategy, by exploiting the exogenous variation generated by the influx of white immigrant speakers following the E.U. enlargement to Eastern European countries in 2005. In their study, they analyse the effect of the share of non-native English speakers on the educational attainment of native English speakers in England. Their results show no sizable negative effects.

Finally, Brunello and Rocco (2011) address the sorting of immigrants within countries by aggregating the test scores of children with an immigrant and a native background at the country level. By virtue of aggregation, they remove the sorting of individuals across schools. However, immigrants can also be sorted between different countries. Using data that vary by country and time, they control for between-country migration flows by conditioning on country fixed effects, country specific trends, per capita GDP, education expenditure and the stock of immigrants in a given country at a given time. Conditional on these covariates, changes in the share of immigrant pupils in each country depend mainly on demographic factors and are as good as random, as pointed out by Gould et al. (2009). Using PISA test scores and data from 19 OECD countries, they find that a higher share of pupils with an immigrant background has small negative effects on the test scores of children of native parents.

Table 5. The Effects of the Share of Immigrants in Class or School on the Performance of Natives and Immigrants. European Studies

\begin{tabular}{|c|c|c|c|c|}
\hline Authors & Estimated effect & Data & Estimation Method & Estimated Effects \\
\hline $\begin{array}{l}\text { Gould et al. } \\
\text { (2009) }\end{array}$ & $\begin{array}{l}\text { Immigrant } \\
\text { concentration on } \\
\text { natives' chances of } \\
\text { passing the high } \\
\text { school matriculation } \\
\text { exam (necessary to } \\
\text { attend college). }\end{array}$ & $\begin{array}{l}\text { Administrative panel } \\
\text { data on school } \\
\text { enrolment and test } \\
\text { scores from } 1993 \text { to } \\
2001 .\end{array}$ & 2SLS & $\begin{array}{l}\text { Natives: substantial } \\
\text { adverse effects. }\end{array}$ \\
\hline $\begin{array}{l}\text { Jensen and } \\
\text { Rasmussen } \\
(2011) \\
\end{array}$ & $\begin{array}{l}\text { Immigrant } \\
\text { concentration on } \\
\text { PISA test scores. }\end{array}$ & $\begin{array}{l}\text { PISA test scores of } \\
\text { 9th grade students in } \\
\text { Denmark }\end{array}$ & 2SLS & Natives: negative effects \\
\hline $\begin{array}{l}\text { Brunello and } \\
\text { Rocco (2013) }\end{array}$ & $\begin{array}{l}\text { Immigrant } \\
\text { concentration on } \\
\text { natives' PISA test } \\
\text { scores. }\end{array}$ & $\begin{array}{l}\text { PISA panel data for } \\
2000-2009 .\end{array}$ & $\begin{array}{l}\text { Aggregation at country } \\
\text { level. }\end{array}$ & $\begin{array}{l}\text { Natives: small negative } \\
\text { effects. }\end{array}$ \\
\hline
\end{tabular}




\begin{tabular}{|c|c|c|c|c|}
\hline $\begin{array}{l}\text { Geay et al. } \\
(2013)\end{array}$ & $\begin{array}{l}\text { Immigrant } \\
\text { concentration on the } \\
\text { test scores of native } \\
\text { English speakers in } \\
\text { England. }\end{array}$ & $\begin{array}{l}\text { National Pupil } \\
\text { Database between } \\
2003 \text { and } 2009 .\end{array}$ & 2 SLS & $\begin{array}{l}\text { Natives: no sizable } \\
\text { negative effects. }\end{array}$ \\
\hline $\begin{array}{l}\text { Ohinata and } \\
\text { Van Ours } \\
(2013)\end{array}$ & $\begin{array}{l}\text { Immigrant } \\
\text { concentration on } \\
\text { PIRLS and TIMSS } \\
\text { test scores }\end{array}$ & $\begin{array}{l}\text { PIRLS and TIMSS } \\
\text { test scores }\end{array}$ & School fixed effects & $\begin{array}{ll}\text { Natives: no sizable } \\
\text { negative effects. } \\
\text { Non-natives: negative } \\
\text { effects }\end{array}$ \\
\hline Contini (2013) & $\begin{array}{l}\text { Immigrant } \\
\text { concentration on } \\
\text { INVALSI test scores }\end{array}$ & INVALSI test scores & School fixed effects & $\begin{array}{l}\text { Natives: no sizable } \\
\text { negative effects. } \\
\text { Non-natives: negative } \\
\text { effects }\end{array}$ \\
\hline $\begin{array}{l}\text { Ballatore et al. } \\
\text { (2014) }\end{array}$ & $\begin{array}{l}\text { Immigrant } \\
\text { concentration on } \\
\text { INVALSI test scores } \\
\end{array}$ & INVALSI test scores & & $\begin{array}{l}\text { Natives: substantial } \\
\text { adverse effects. }\end{array}$ \\
\hline $\begin{array}{l}\text { Schneeweis } \\
(2015)\end{array}$ & $\begin{array}{l}\text { Immigrant } \\
\text { concentration in } \\
\text { Austrian primary } \\
\text { schools on } \\
\text { repetition in primary } \\
\text { and secondary schools } \\
\text { and track attendance } \\
\text { after primary } \\
\text { education. }\end{array}$ & $\begin{array}{l}\text { Register data covering } \\
22 \text { school cohorts of } \\
\text { compulsory school } \\
\text { students in Linz. }\end{array}$ & $\begin{array}{l}\text { Variation in the fraction } \\
\text { of migrant students } \\
\text { among cohorts within } \\
\text { schools. }\end{array}$ & $\begin{array}{l}\text { Natives: no sizable } \\
\text { negative effects } \\
\text { Non-natives: negative } \\
\text { effects. }\end{array}$ \\
\hline Tonello (2015) & INVALSI test scores & $\begin{array}{l}\text { Administrative data } \\
\text { covering the census of } \\
\text { Italian junior high } \\
\text { schools }\end{array}$ & $\begin{array}{l}\text { Variation in the fraction } \\
\text { of migrant students } \\
\text { among cohorts within } \\
\text { schools }\end{array}$ & $\begin{array}{l}\text { Natives: weak negative } \\
\text { impact }\end{array}$ \\
\hline
\end{tabular}

Note: 2SLS: two stages least squares.

Overall, the available evidence suggests that students with an immigrant background are negatively affected by other immigrant students in the class or school. Students with a native background are also negatively affected, but the size of the estimated effect is controversial, ranging from very small to considerable. From a policy perspective, it is clear that the minuses from school or class segregation by ethnic group prevail over the pluses only for children with an immigrant background.

\section{Attitudes toward immigration and education}

The integration process of immigrants is affected not only by their behaviour and by their decisions in terms of human capital investments but also by the attitudes of citizens in the hosting country. The opposition to immigration is typically related both to economic and non-economic concerns. On the one hand, native individuals might feel threatened by the competition in the labour market that arises from immigration (Scheve and Slaughter, 2001; Mayda, 2006). On the other hand, independent of economic considerations, anti-immigration sentiments might derive from racial intolerance and cultural and ethnic tensions between native individuals and immigrant populations (Dustmann and Preston, 2007; Citrin et. Al, 1997; O'Rourke and Sinnott, 2006; Hainmueller and Hiscox, 2010). 
In this section, we briefly discuss whether higher education of the native population mitigates antiimmigration sentiments. This could happen for different reasons. First, education may reduce the economic concerns that might lie at the heart of negative attitudes toward immigrants. Since these concerns originate in the presumed degree of substitutability of immigrants and natives, education can protect natives from the competition of immigrants by increasing the labour market complementarity between these two groups. Secondly, education, by increasing knowledge and the ability to interpret information, allows individuals to better balance the pros and the cons of immigration. Finally, since education transmits norms of tolerance and equality, it might foster humanitarian and egalitarian sentiments among the native population, combating cultural and racial prejudices.

Empirical evidence shows that education is the most relevant predictor of attitudes towards immigrants in the host country. Better educated individuals are more open, have stronger preferences for cultural diversity and a more favourable attitude toward foreign immigrants (Card et al., 2009; Boeri, 2010 Hainmueller and Hiscox, 2007). This evidence suggests that more educated individuals are less likely to have prejudices against immigrants.

Nevertheless, the positive correlation between education and immigration attitudes, found by most of the empirical research in the area, cannot be interpreted as a causal effect. In fact, there are many individual unobserved characteristics that might affect both investments in education and immigration attitudes. As far as we know, only few papers have tried to overcome these problems using either longitudinal data or instrumental variable strategies. While most of the existing literature uses crosssectional data, Hooghe et al. (2013) and Lancee and Sarrasin (2015) rely on longitudinal data. Hooghe et al. (2013) investigate changes in the attitudes towards immigrants during late adolescence and early adulthood in Belgium (at 16, 18, and 21 years old). Estimating a random fixed effects model, they show that 16-year old adolescents with higher education have more positive initial attitudes towards immigrants, and that the gap with lower educated individuals widens as they grow older.

Unfortunately, their contribution does not adequately address the bias induced by selection into education. Lancee and Sarrasin (2015), address this problem by estimating an individual fixed effects model using data from the Swiss Household Panel, which contains information on attitudes towards immigrants at two points in time, when individuals are adolescents (at age 13) and when they are young adults (at 30). Controlling for individual fixed effects eliminates any bias due to unobserved time invariant individual characteristics which might affect both education and attitudes toward immigrants. For instance, attitudes toward immigrants might be affected by some psychological traits, such as openness or self-confidence, which also affect investments in human capital. Omitting these variables (typically not observable to the researcher in the analysis) would produce a downward or an upward bias, depending on the effect that these traits have on the variable of interest. However, if these traits are constant over time, individual fixed effects eliminate this source of bias since they rely exclusively 
on the variation within each individual over time. Lancee and Sarrasin (2015) show that the differences in attitudes toward immigrants tend to disappear when changes within individuals are examined. Although individual fixed effects estimates take into account confounding time invariant individual unobserved characteristics, one cannot exclude that their findings are still biased by the presence of time variant unobserved features. Over time, a number of unobservable factors might have changed affecting both individual investments in education and attitudes toward immigrants.

A different estimation strategy is used by D’Hombres and Nunziata (2015), who use the reforms in compulsory education that took place in Europe in the period 1960- 1990 as a source of exogenous variation in education. Their analysis is based on the European Social Survey data from 2002 to 2010 and Eurostat Labour Force Survey data from the same period and exploit the fact that different birth cohorts have been exposed to the reforms to a different extent. They show that education leads to a more positive attitude toward immigrants, irrespective of their ethnicity and their continent of origin. As far as the mechanism behind this effect is concerned, their findings suggest that both economic and non-economic factors might play a role. On the one hand, they show that individuals with higher education select into occupations that are less exposed to the negative externalities of migration. On the other hand, they show that the positive effect of education on attitudes toward immigrants remains also when considering only individuals who are insulated from economic competition, suggesting that noneconomic channels may also be at work.

Overall, the evidence that uses robust estimation strategies to identify the effects that education has on the immigration attitudes of citizens is still very scant. Because of this, it is not possible to derive general conclusions. Additional research is necessary in order to understand whether education can represent a crucial tool in integration and assimilation of immigrants.

\section{Conclusions}

In this paper, we have reviewed the issues surrounding the role of education for the economic integration of immigrants. Our assessment of the empirical literature points at the following main facts:

- in general, immigrants in Europe are less educated than native individuals, but there is large heterogeneity among countries. While some countries, including the UK and Ireland, are characterised by a high-skilled foreign-born population, others, such as France, Germany and the Netherlands, have mainly a low-skilled foreign-born population;

- children with an immigrant background generally have higher education than their parents, but in many countries they still fall behind natives. Heterogeneity across countries is relevant. While 
no significant differences are detected for the Anglo-Saxon European countries, there are in Central and Northern European countries significant achievement gaps;

- while in some countries the causes of educational gaps can be imputed to differences in socioeconomic background and to deficiencies in the host language proficiency, in other countries the sources of these gaps are not easy to identify as they persist even after controlling for a vast array of individual characteristics.

These facts and the heterogeneity across countries point out that policies required to foster the integration of immigrants are likely to vary across countries.

In the second part of our report we have analysed the recent economic literature looking at the importance of institutional features for the educational outcomes of immigrant children. We have focused our attention on pre-school attainment, the combination of teacher and student demographic characteristics and school tracking. Our key results can be summarized as follows:

- programs providing immigrant children with adequate access to pre-school services might be a sensible policy to improve their short and long-term educational outcomes;

- training programs aimed at changing stereotyped teacher attitudes toward immigrants might also be useful to bust immigrant children educational performance;

- recruiting teachers with an immigrant background can help immigrant children by establishing positive role models;

- while in general late tracking does not help to reduce immigrant-native education gaps, it might be useful for children from less integrated families, who lack proficiency in the national language.

We have also examined how peer effects impact the school performance of native and immigrant students. Here, the available evidence suggests that students with an immigrant background are negatively affected by other immigrant students in the class or school. For native children, results are controversial, with some studies showing negligible negative effects, and other studies showing substantial negative spill-overs. Designing adequate policies in this context is difficult, because measures that discourage segregation may help one group but hurt another group, and therefore induce native parents to move their children out of mixed schools. A solution might be to avoid the concentration of immigrant students in the same class. However, evidence in support of such policy is still scant.

A number of European countries have implemented a host of different policies aimed at closing the "native-immigrant" educational gap. Some of these policies are targeted at very young children and at their parents to enhance children's readiness for schooling (Austria, The Netherlands), others involve students attending primary and secondary school and are aimed at improving their learning of the host country's language (Bulgaria, Denmark, France, Germany, Sweden, Switzerland, UK). Some countries 
have also experimented with: programs offering out-of-school activities (Denmark, Germany); programs promoting multilingualism in the classroom (Belgium, France, Greece, Ireland, UK) and mother tongue learning (Austria, Belgium, Germany, UK, Sweden). Policies aiming at adapting teaching approaches to the needs of immigrants have also been pursued (in France, Germany, Ireland Switzerland, the Netherlands, UK). These policies seem to go in the right direction. Some studies trying to evaluate their effects find positive results. For instance, Berton and White (2007) look at a project implemented in the UK (Raising the Achievement of Bilingual Learners in Primary Schools), that provides training to teachers in order to enable them to meet the needs of children who do not speak the language of instruction, and find that it has positive effects on language skills but no effects on math and science competencies.

Unfortunately, rigorous evaluation studies that try to quantify the costs and benefits of each policy are missing. This can be due to the fact that in many cases policies are not designed to include sources of exogenous variation in the treatment. As discussed in Brunello and De Paola (2013), policy design plays a crucial role in allowing researchers to identify causal effects and quantify the impact of policies on outcome variables. 


\section{References}

Adesope O. (2010), A Systematic Review and Meta-Analysis of the Cognitive Correlates of Bilingualism, Review of Educational Research, 80(2), 207-245.

Algan, Y., C. Dustmann, A. Glitz and A. Manning (2010), The economic situation of first and second-generation immigrants in France, Germany and the United Kingdom, Economic Journal, 120(542), F4-F30.

Anderson, M. L. (2008). Multiple Inference and Gender Differences in the Effects of Early Intervention: A Reevaluation of the Abecedarian, Perry Preschool, and Early Intervention Training Projects. Journal of the American Statistical Association 103(484), 1481-1495.

Austen-Smith R. and R. Fryer (2005), An economic analysis of "acting white", Quarterly Journal of Economics, pp. 551-583.

Aydemir, A., W.-H. Chen and M. Corak (2009), "Intergenerational Earnings Mobility Among the Children of Canadian Immigrants", Review of Economics and Statistics, Vol. 91 (2), 377-397.

Ballatore R., Fort M., Ichino A. (2014), The Tower of Babel in the Classroom: Immigrants and Natives in Italian Schools, wp IZA. 8732.

Bardak U. (2014), Migration and Skills Development Agenda in ETF partner countries. ETF position paper, European Training Foundation, Turin.

Benton, T. and White, K. (2007), Raising the achievement of bilingual learners in primary schools: statistical analysis, Department for Children, Schools and Families UK.

Berlinski, S., S. Galiani and P. Gertler (2009): "The effect of pre-primary education on primary schools performance". Journal of Public Economics 93, 219-234.

Betts, J.R. and Fairlie, R.W. (2003), "Does immigration induce native flight from public schools into private schools?”, Journal of Public Economics, vol. 87(5-6) (May), pp. 987-1012.

Biedinger, N., Becker, B., and Rohling, I. (2008), Early Ethnic Educational Inequality: The Influence of Duration of Preschool Attendance and Social Composition, European Sociological Review, 24, 243-256.

Bleakley, H., Chin, A., (2004), Language skills and earnings: evidence from childhood immigrants. Rev. Econ. Stat. 86 (2), 481-496.

Bleakley, H., Chin, A., (2010), Age at arrival, English proficiency, and social assimilation among U.S. immigrants. Am. Econ. Rev. Appl. Econ. 2 (1), 165-192

Boeri, T. (2010). Immigration to the land of redistribution, Economica, 77 (308), 651-687.

Borjas, G. J. (1992), "Ethnic Capital and Intergenerational Mobility”, Quarterly Journal of Economics, Vol. 107 (1), 123-150.

Borjas, G. J. (1995), "Ethnicity, Neighborhoods, and Human-Capital Externalities", American Economic Review, Vol. 85 (3), 365-390.

Brunello G. and De Paola M. (2013), The costs of early school leaving in Europe, EENEE (The European Expert Network on Economics of Education) Report.

Brunello, G. and L. Rocco (2011), "The Effect of Immigration on the School Performance of natives: Cross Country Evidence Using PISA Test Scores", IZA DP No. 5479.

Brunello, G. and D. Checchi. (2007) "Does school tracking affect equality of opportunity? New international evidence." Economic Policy 22, no. 52: 781-861.

Budra, S., Swedberg, P., (2012) The impact of language proficiency on immigrants earnings in Spain. IZA Discussion Paper No. 6957.

Burgess S.M. and Greaves E. (2013), Test scores, subjective assessment and stereotyping of ethnic minorities, Journal of Labor Economics, 31 (3), pp. 535-576. 
Campbell, F. A., C. T. Ramey, E. Pungello, J. Sparling and S. Miller-Johnson (2002): Early Childhood Education: Young adult outcomes from the Abecedarian Project, Applied Developmental Science, 6(1), 42-57.

Card, D., Dustmann, C. and Preston, I. (2009). Immigration, Wages, and Compositional Amenities. NBER Working Papers 15521, National Bureau of Economic Research, Inc.

Carliner G. (1981), Wage differences by language group and the market for language skills in Canada, Journal of Human Resources, 16(3), 384-399.

Cascio, E. (2009): "Do investments in universal early education pay off? Long-term effects of introducing kindergartens into public schools". NBER Working Paper 14951.

Chin, A. and N. Daysal and S. A. Imberman (2012), "Impact of Bilingual Education Programs on Limited English Proficient Students and Their Peers: Regression Discontinuity Evidence from Texas," NBER Working Paper N.18197.

Chiswick, B.R. and N. DebBurman (2004), Educational attainment: analysis by immigrant generation, Economics of Education Review, 23(4), 361-79.

Chiswick, B.R., (1998) Hebrew language usage: determinants and effects on earnings among immigrants in Israel. J. Popul. Econ. 11 (2), 253-271.

Chiswick, B.R., Miller, P.W., (1995), The endogeneity between language and earnings: international analyses. J. Labor Econ. 13 (2), 246-288.

Chiswick, B.R., Miller, P.W., (2014), International migration and the economics of language. In: Chiswick, B.R., Miller, P.W. (Eds.), Handbook of the Economics of Immigration. Elsevier 211-269.

Citrin J., C. M., Donald P. Green and Wong, C. (1997). Public opinion toward immigration reform: The role of economic motivations. The Journal of Politics, 59 (3),858-881.

Clair L., Jackson B., and Zweiback R. (2012), Six Years Later: Effect of Family Involvement Training on the Language Skills of Children From Migrant Families, School Community Journal, 22(1), pp. 9-19.

Clair, L., Jackson, B. (2006), 'Effect of Family Involvement Training on the Language Skills of Young Elementary Children from Migrant Families', School Community Journal, 16, 31-42.

Cobb-Clark, D. A., Sinning, M., and Stillman, S. (2012). Migrant Youths' Educational Achievement: The Role of Institutions. ANNALS of the American Academy of Political and Social Science, 643(1):18\{45.

Coleman, J. S., Campbell, H. Q., Hobson, C. J., McPartland, J., Mood, A. M., Weinfeld, F. D., and York, R. L. (1966). Equality of Educational Opportunity. U.S. Office of Education, Washington, DC.

Contini D. (2013) Immigrant background peer effects in Italian schools, Social science research, 43(4), 11221142

Cooley Jane (2010), "Desegregation and the achievement gap: do diverse peer matter?", mimeo University of Wisconsin-Madison.

Crul, M., Schneider, J. and Lelie, F. (Eds.). (2012). The European Second Generation Compared. Does the Integration Context Matter? Amsterdam: Amsterdam University Press.

D'Hombres B. and Nunziata L. (2015), Wish You Were Here? Quasi-Experimental Evidence on the Effect of Education on Attitude toward Immigrants, IZA DP No. 8880

Dee, T. (2004), Teachers, Race, and Student Achievement in a Randomized Experiment, Review of Economics and Statistics 86 (1): 195-210.

Dee, T. (2005), A Teacher Like Me: Does Race, Ethnicity, or Gender Matter?” American Economic Review 95 (2): $158-65$.

Di Paolo, A., Raymond, J.L., (2012), Language knowledge and earnings in Catalonia. J. Appl. Econ. 15 (1), 89118.

Docquier, F. and A. Marfouk (2004), Measuring the international mobility of skilled workers - Release 1.0, Policy Research Working Paper n. 3382, World Bank (August 2004). 
Docquier, F. and Marfouk A. (2006), International Migration by Educational Attainment (1990-2000)-Release 1.1; IWEPS, Regional government of Wallonia (Belgium)

Drange, N., and K. Telle (2015), Promoting integration of immigrants: Effects of free child care on child enrollment and parental employment, Labour Economics, Volume 34, Pages 26-38.

Dustmann, C., (1994), Speaking fluency, writing fluency and earnings of migrants. J. Popul. Econ. 7 (2), 133-156.

Dustmann, C. (2008), "Return Migration, Investment in Children, and Intergenerational Mobility: Comparing Sons of Foreign- and Native-Born Fathers", Journal of Human Resources, Vol. 43 (2), 299-324.

Dustmann C., Frattini T. (2011), Immigration: The European Experience, Centro Studi Luca D’Agliano Development Studies, wp. 326.

Dustmann C., Frattini T., Lanzara G. (2012), Educational achievement of second-generation immigrants: an international comparison, Economic Policy, pp. 143-185

Dustmann, C. and Frattini, T. (2013). The Fiscal Effects of Immigration to the UK. CReAM Discussion Paper Series 1322, Centre for Research and Analysis of Migration (CReAM), Department of Economics, University College London.

Dustmann, C. and Glitz A. (2011), Migration and education', in E.A. Hanushek, S. Machin and L. Woessmann (eds.), Handbook of the Economics of Education (vol. 4, ch. 4), North-Holland, Amsterdam.

Dustmann, C. and N. Theodoropoulos (2010), Ethnic minority immigrants and their children in Britain, Oxford Economic Papers, 62(2), 209-33.

Dustmann, C., A. Raute, and U. Schoenberg (2013), Does Universal Child Care Matter? Evidence from a Large Expansion in Pre-School Education," mimeo, UCL.

Dustmann, C., Fabbri, F., (2003), Language proficiency and labour market performance of immigrants in the UK. Econ. J. 113 (489), 695-717.

Dustmann, C., van Soest, A., (2001), Language fluency and earnings: estimations with misspecified indicators. Rev. Econ. Stat. 83 (4), 663-674.

Dustmann, C., van Soest, A., (2002), Language and the earnings of immigrants. Ind. Labor Relat. Rev. 55 (3), 473-492.

European Commission (2015), Language teaching and learning in multilingual classrooms, Brussels

European Commission, (2011), Communication on Migration, 248 final, Brussels

Fairlie R., F. Hoffmann, and P. Oreopoulos (2014), A Community College Instructor Like Me: Race and Ethnicity Interactions in the Classroom, American Economic Review, 104(8): 2567-2591

Feld J., Salamanca N. and Hamermesh D. (2013) Endophilia or Exophobia: Beyond Discrimination, NBER wp 19471

Felfe C. and Huber M. (2015), Does preschool boost the development of minority children? The case of Roma children; wp n.455, University of Fribourg.

Friesen J. and Krauth B. (2011), Ethnic enclaves in the classroom, Labour Economics, 18(5), 656-663.

Gang, I.N. and K.F. Zimmermann (2000), Is child like parent? Educational attainment and ethnic origin, Journal of Human Resources, 35(3), 550-69.

Geay, C., S. McNally, and S. Telhaj (2013). Non-native speakers of English in the classroom: What are the effects on pupil performance? The Economic Journal 123 (570),F281-F307.

Giannelli, G. and Rapallini, C. (2015), Immigrant Student Performance in Math: Does It Matter Where You Come From?, IZA Discussion Papers 9019, Institute for the Study of Labor (IZA).

Gormley, W., and T. Gayer (2008), The Effects of Oklahoma_s Pre-K Program on Hispanic Children, Social Science Quarterly, 89(4), 916\{936. 
Gormley, W., T. Gayer, D. Phillips, and B. Dawson (2005): The E_ects of Universal Pre-K on Cognitive Development, Development Psychology, 41(6), 872884.

Gould, E. D., V. Lavy and M. D. Paserman (2009), "Does immigration affect the long-term educational outcomes of natives? Quasi-experimental evidence", The Economic Journal 119(540): 1243-1269.

Hainmueller J. and Hiscox, M. J. (2007), Attitudes toward highly skilled and low-skilled immigration: Evidence from a survey experiment. American Political Science Review, 104, 61-84.

Hainmueller, J. and Hiscox, M. J. (2007). Educated preferences: Explaining attitudes toward immigration in europe. International Organization, 61, 399-442.

Hanushek E. and Rivkin S. (2009), Harming the Best: How Schools Affect the Black-White Achievement Gap," Journal of Policy Analysis and Management, Vol. 28, No. 3, 366-393.

Hanushek E. and Woessmann L. (2005), Does educational tracking affect performance and inequality? Difference-in-difference evidence across countries, Economic Journal, 116(510):C63-C76

Hanushek E. and Woessmann, L. (2012), Do better schools lead to more growth? Cognitive skills, economic outcomes, and causation, Journal of Economic Growth, Springer, vol. 17(4), pages 267-321, December

Hanushek, Eric A., John F. Kain and Steven G. Rivkin (2009), "New Evidence About Brown V. Board of Education: The Complex Effects of School Racial Composition on Achievement", Journal of Labor economics, 2009 , vol. 27 , no. 3 .

Havnes, T. and M. Mogstad (2009), "No Child Left Behind: Universal Child Care and Long-Run Outcomes", IZA Discussion Paper No. 4561.

Heckman J., "Policies to Foster Human Capital," (with Discussion), Research in Economics, (2000), 54(1), 3-56.

Hinnerich B., Höglin E. and Johannesson M. (2015), Discrimination against students with foreign backgrounds: evidence from grading in Swedish public high schools, Education Economics, 23:6, 660-676,

Hooghe M., Meeusen C., Quintelier E. (2013). The impact of education and intergroup friendship on the development of ethnocentrism. A latent growth curve model analysis of a five-year panel study among belgian late adolescents. European Sociological Review, 29(6), 1109-1121.

Hoxby, Caroline M. (2000), "Peer Effects in the Classroom: Learning from Gender and Race Variation", National Bureau of Economic Research: Working Paper No. 7867.

International Migration Outlook (2014), OECD

Isphording I. and Otten (2011), Linguistic distance and the language fluency of immigrants, Ruhr Economic Paper, 274

Jansen, Peter and Astrid W. Rasmussen (2008), "Immigrant and Native Children"s Cognitive Outcomes and the Effect of Ethnic Concentration in Danish Schools", The Rockwool Foundation Research Unit, Study Paper No. 20, University Press of Southern Denmark, Odense.

Kiss, D. (2011), “Are Immigrants and Girls Graded Worse? Results of a Matching Approach.” Education Economics 21 (5): 447-463.

Lahaie, C. (2008), School Readiness of Children of Immigrants: Does Parental Involvement Play a Role?," Social Science Quarterly, 89, 684-705.

Lancee B. and Sarrasin O. (2015), Educated Preferences or Selection Effects? A Longitudinal Analysis of the Impact of Educational Attainment on Attitudes Towards Immigrants, European Sociological Review, 1-12.

Levels, M., and Dronkers, J. (2008). Educational performance of native and immigrant children from various countries of origin. Ethnic and Racial Studies, 31(8): 1404-1425.

Levels, M., Dronkers, J., and Kraaykamp, G. (2008). Immigrant children's educational achievement in western countries: origin, destination, and community effects on mathematical performance. American Sociological Review, 73(5), 835-853.

Lindahl E.(2015), Are teacher assessments biased? Evidence from Sweden, Education Economics. 
Lleras-Muney, A. and A. Shertzer (2015), "Did the Americanization Movement Succeed? An Evaluation of the Effect of English-Only and Compulsory Schooling Laws on Immigrants." American Economic Journal: Economic Policy, 7(3): 258-90.

Lüdemann L. and Schwerdt G. (2013), Migration background and educational tracking Is there a double disadvantage for second-generation immigrants? Journal of Population Economics, 26, pp. 455-481.

Lusher L., Campbell D., Carrell S. (2015), TAs Like Me: Racial Interactions between Graduate Teaching Assistants and Undergraduates, NBER Working Paper No. 21568.

Maestri, V. (2011). Can ethnic diversity have a positive effect on school achievement? Munich Personal RePEc Archive.

Mallows D. (2014), Language issues in migration and integration: perspectives from teachers and learners, British Council 2014.

Mayda, A. (2006). Who is against immigration? a cross-country investigation of individual attitudes toward immigrants. The Review of Economics and Statistics, 88 (3), 510-530.

Matsudaira, J. (2005), "Sinking or Swimming? Evaluating the Impact of English Immersion versus Bilingual Education on Student Achievement." University of California, Berkeley, mimeo

McManus W, W Gould, F Welch (1983), Earnings of Hispanic men: The role of English language proficiency, Journal of Labor Economics, 1(2), 101-130.

Meluish, E., K. Sylvia, P. Sammons, I. Siraj-Blatchford and B. Taggart (2004): The Effective Provision of PreSchool and Primary Education (EPPE) Project. Findings from Pre-School to end of Key Stage 1, SSU Report,

Miranda, A., Zhu, Y., (2013a), The causal effect of deficiency at English on female immigrants' labor market outcomes in the UK, IZA Discussion Paper No. 7841.

Miranda, A., Zhu, Y., (2013b), English deficiency and the native immigrant wage gap. Economic Letters, 118 (1), $38-41$.

Murat M. (2011), Do immigrant students succeed? Evidence from Italy and France based on PISA 2006, mimeo.

Nusche, D. (2009), 'What Works in Migrant Education? A Review of Evidence and Policy Options', OECD Education Working Papers, No. 22. OECD Publishing.

OECD (2013), 'The Challenge of Diversity', in PISA 2012 Results: Excellence through Equity (Volume II): Giving Every Pupil the Chance to Succeed, OECD Publishing.

Ohinata, A. and J. C. van Ours (2013). How immigrant children affect the academic achievement of native Dutch children. Economic Journal 123, F308-F331.

O'Rourke, K. H. and Sinnott, R. (2006). The determinants of individual attitudes towards immigration. European Journal of Political Economy, 22 (4), 838-861.

Pekkarinen, T., R. Uusitalo and S. Kerr (2009). School tracking and intergenerational income mobility: Evidence from the Finnish comprehensive school reform, Journal of Public Economics, 93, 965-973

Riphahn, R.T. (2003), Cohort effects in the educational attainment of second generation immigrants in Germany: an analysis of census data, Journal of Population Economics, 16(4), 711-37.

Rosenthal, R., and Jacobson, L. (1968). Pygmalion in the classroom. New York: Holt, Rinehart \& Winston.

Rouse, C., Brooks-Gunn, J., and McLanahan, S. (2005), "Introducing the Issue. School Readiness: Closing Racial and Ethnic Gaps," The Future of Children, 15.

Ruhose J. and Schwerdt G. (2015), Does Early Educational Tracking Increase Migrant-Native Achievement Gaps? Differences-In-Differences Evidence Across Countries, CESIFO WORKING PAPER NO. 5248

Scheve, K. and Slaughter, M. (2001). Labor-market competition and individual preferences over immigration policy. Review of Economics and Statistics, 83 (1), 133-145. 
Schneeweis N. (2015), Immigrant concentration in schools: Consequences for native and migrant students, Labour Economics, 35, pp.53-76.

Schnepf S. (2007), Immigrants' educational disadvantage: an examination across ten countries and three surveys, Journal of Population Economics, 20, 527-545.

Schuetz, G., H. Ursprung and L. Wößmann (2008). 'Education policy and equality of opportunity', Kyklos, CESIFO Working Paper 1518.

Sprietsma M. (2009), Discrimination in Grading? Experimental Evidence from Primary School, mimeo

Sweetman A. and van Ours J. (2014), Immigration: What About the Children and Grandchildren? CentER Discussion Paper Series No. 2014-009.

Tonello M. (2015), Peer effects of non-native students on natives' educational outcomes: mechanisms and evidence, Empirical Economics, forthcoming

Van Ewijk R. (2011), Same work, lower grade? Student ethnicity and teachers' subjective assessments, Economics of Education Review,

Van Ours, J.C. and J. Veenman (2003), The educational attainment of second-generation immigrants in The Netherlands, Journal of Population Economics, 16(4), 739-53.

Yao Y. and van Ours J. (2015), Language skills and labor market performance of immigrants in the Netherlands, Labour Economics, Volume 34, Pages 76-85 